\title{
Depositional architecture and peculiar sedimentary features of Late Cretaceous Utrillas Formation at Tamajón (Guadalajara, Spain)
}

\author{
J.F. García-Hidalgo'*, J. Gil-Gil ${ }^{1}$, M. Segura ${ }^{1}$, B. Carenas ${ }^{2}$ \\ ${ }^{1}$ Departamento de Geología, Geografía y Medio Ambiente (Grupo IberCreta). Universidad de Alcalá. 28871 Alcalá de Henares. Spain \\ ${ }^{2}$ Departamento de Geología y Geoquímica (Grupo IberCreta). Universidad Autónoma de Madrid. 28049 Madrid. Spain
}

e-mail addresses: jose.garciahidalgo@uah.es (J.F.G.-H., *Corresponding author); javier.gil@uah.es (J.G.G.); manuel.segura@uah.es (M.S.); beatriz.carenas@uam.es (B.C.)

Received: 27 July 2016 / Accepted: 14 November 2016 / Available online: 20 December 2016

\begin{abstract}
The Utrillas Formation represents clastic wedges that accumulated in relation to continental-coastal areas of Iberian Basin during the worldwide Late Cretaceous sea-level rise. At the Tamajón outcrop the Late Cenomanian Utrillas wedges are composed of four facies associations (FA1 to FA4), which unconformably overlay Triassic deposits. Basal sediments (FA1) are interpreted as high energy, braided fluvial deposits, characterized by coarse-grained (conglomerate-sandstone) facies; which grade upwards to tide-influenced, estuarine sedimentation (sandstones and mudstones with inclined heterolithic stratification, FA2), and then to high-energy, coastal sheet and channelled sandstones with different tidal features (FA3); and finally, to fine-grained (mudstones and minor burrowed sandstones) of an offshore marine associations (FA4). The depositional architecture based in the presence and hierarchy of several ranks of bounding surfaces and the overall upward-fining succession show the long term retrogradational trend of these facies associations. Peculiar sedimentary features of these sediments are 1) the presence of large-scale, single sets of cross beds infilling large erosive channels, which are tidal in origin. 2) The size and length of the cross-bedding defined by couplets of different grain size; here interpreted as originated by flow unsteadiness in relation to changing tides. And 3) an unusual association of ironstones, wrinkle structures and vertebrate tracks with microbial mats and penecontemporaneous iron encrusting allowing track preservation in the sedimentary record.
\end{abstract}

Keywords: continental-coastal facies, large-scale channels, ferruginous crusts, wrinkle marks, vertebrate tracks, Cenomanian.

Resumen

La Formación Utrillas está compuesta por una serie de cuñas clásticas que se depositaron en las áreas continentales y costeras de la Cuenca Ibérica durante el ascenso eustático global del Cretácico Superior. En el afloramiento de Tamajón las cuñas del Cenomaniense Superior de la Formación Utrillas están compuestas por 4 asociaciones de facies (FA1 a FA4), que se disponen discordantes sobre materiales triásicos. Los sedimentos basales (FA1) se interpretan como depósitos de sistemas fluviales de tipo braided, de alta energía, caracterizados por facies de grano grueso (conglomerados y areniscas); que pasan hacia techo a facies estuarinas con influencia mareal (areniscas y lutitas con estratificación heterolítica inclinada, FA2), y estas a areniscas tabulares y canalizadas costeras de alta energía que presentan diferentes características mareales (FA3); y, finalmente la sucesión da paso a una asociación marina somera (FA4), de grano fino y baja energía (lutitas con areniscas bioturbadas subordinadas). La arquitectura deposicional se basa en la presencia y jerarquía de varios rangos de superficies erosivas y la tendencia granodecreciente general de la sucesión, que caracteriza la tendencia retrogradacional general de esas asociaciones de facies. Los materiales estudiados presentan una serie de características sedimentarias peculiares tales como: 1) la presencia de grandes canales fuertemente erosivos rellenos con un único set de estratificación cruzada de gran escala, de origen mareal. 2) El tamaño y longitud de las propias estratificaciones cruzadas, definidas por parejas de láminas de diferente tamaño de grano, interpretadas como originadas por variaciones en el flujo de la corriente en relación con el sistema mareal. Y 3) una asociación poco frecuente de costras ferruginosas, estructuras de tipo wrinkle y huellas de vertebrados, que suponen el desarrollo de láminas microbianas y encostramientos ferruginosos penecontemporaneos los cuales permitieron a su vez la preservación de las huellas en el registro sedimentario.

Palabras clave: facies continentales-costeras, grandes canales, costras ferruginosas, wrinkle marks, huellas de vertebrados, Cenomaniense 


\section{Introduction}

Continental and coastal sedimentary environments were widespread developed in epi- and intracontinental basins during high sea level periods, such as the Late Cretaceous, because large areas of the continents were flooded by shallow seas, as sea level rose during these times. Description of the controls on continental and marine facies and facies associations in these systems involves thorough analysis of continuous, laterally extensive outcrops that allows for the reconstruction of 3D geometries and trends of architectural elements together with their mutual relationship. Several problems can be undertaken in these environments mainly related to the own sedimentary environment development and interpretation.

At these environments, the distinctions between different environments and stream processes are difficult to distinguish, especially where continental-coastal transitions occur. Besides, both the absence of fossils and the lack of definite sedimentary structures, that could serve as diagnostic of marine reworking (either tidal, waves or currents), are important problems in the analysis of ancient successions.

Here, we studied continental-coastal, coarse-grained sediments of the Utrillas Formation (Guadalajara province, central Spain) that provide a good example of these continentalcoastal transition, as they were deposited in a coastal area at the western part of the Iberian Basin (Fig. 1a). The Utrillas Formation is a highly heterochronous unit composed of a pile of clastic wedges that ranges in age from the Albian to the Campanian (Gil et al., 2004). In this study we concentrate on the Late Cenomanian clastic wedges of this unit.

The principal aim of our study is to reconstruct the particular palaeoenvironments of the Utrillas Formation by means of lithofacies and sedimentological analysis. Along this study, the presence either of: 1) peculiar cross-bedding and large channels (up to $4 \mathrm{~m}$ thick) locally filled up with a single set of coarsegrained, cross-bedded sandstones and conglomerates, 2) crossbedding defined by long and thick couplets of different grain sizes and 3) ironstones, wrinkle structures (probably microbially-induced sedimentary structures, MISS) and vertebrate tracks, and their mutual relationships were proven as interesting examples, not described previously (3, ironstones, wrinkle and vertebrate tracks) or that can lead to sedimentary environment misinterpretation (1, large-scale, cross bedded sands).

\section{Geological setting}

The late Cenomanian siliciclastic sediments of the Utrillas Formation represent a pile up of thick clastic wedges (Fig. $1 b$ ), that accumulated in relation to the linear western margin of Iberian Basin along the Late Cretaceous (Fig. 1a). This is an intracontinental basin developed since the Late Permian (González-Casado et al., 1996). Its tectonic history is related to complex breakup of the Pangea supercontinent with two phases of rifting and post-rifting sedimentation (Salas and Casas, 1993).

The Utrillas Formation constitutes the continental-coastal sediments of the Late Cretaceous sedimentary successions in the Iberian Basin (Fig. 1a) and, in the studied area, rests unconformably on a thick succession of red sandstones and mudstones of Triassic age (Portero et al., 1990) (Fig. 1b). Biostratigraphic study of this interval was carried out in the more central areas of the Basin (east of the study area; Ibdes and Nuévalos, Fig. 1b) by Wiedmann (1975), Mojica and Wiedmann (1977), and Segura and Wiedmann (1982); based on these works, the Cenomanian/Turonian boundary is located at the top of the studied interval. The Utrillas Formation is conformably overlaid by the Picofrentes Formation; the common presence of Ammonites in the marls of this unit indicates an Early Turonian age for this unit (García-Hidalgo et al., 2007).

The Utrillas Formation consists of continental to marginal marine, unfossiliferous sandstones with some intercalated mudstones and conglomerates. The conspicuous presence of large-scale cross-bedding, the own cross-bedding composed of an alternation of laminae of different grain sizes, and ironstones related to wrinkle marks and an isolated bed with abundant tetrapod tracks and other trace fossils (Segura et al., 2016) are also peculiar.

Previous studies on the Utrillas Formation in this area regarded the Late Cenomanian environments as a low-sinuosity fluvial unit (Portero et al., 1990), with muddy floodplain deposits and some meandering channels predominating at the top of the unit (Hernaiz et al., 2005). More recently, it has been interpreted as continental alluvial and coastal plain (estuarine) deposits (García-Hidalgo et al., 2007).

Palynological data on the Upper Cenomanian in the Iberian Peninsula are scarce. Studies from the northern Iberian Basin, Portugal and other European outcrops are summarized by Diéguez et al. (2010). These authors suggest the presence of subtropical open forest communities dominated by angiosperms, with an abundant gymnosperm component dominated by Classopollis and, to a lesser extent, by conifers such as Taxodiaceae-Cupressaceae, Pinaceae and Araucariaceae; Pteridophytes, however, seem to have played a less significant role in the plant communities of this interval. In the wettest areas an understory possibly composed of vascular cryptogams was also important; meanwhile, the probably most arid or saline coastal vegetation would be Araucariaceae and Cheirolepidiaceae forests (Peyrot et al., 2008).

In the nearby Somolinos section, the palynological data of the overlying sequences (uppermost Cenomanian-Turonian), whose marginal sediments resemble those studied here (García-Hidalgo et al., 2007), suggest that the Iberian hinterland was dominated by an open forest of angiosperms, with scarce, small-sized conifers, and a forest understory not welldeveloped (Gil-Gil et al., 2013), similar to those described for the Late Cenomanian. 


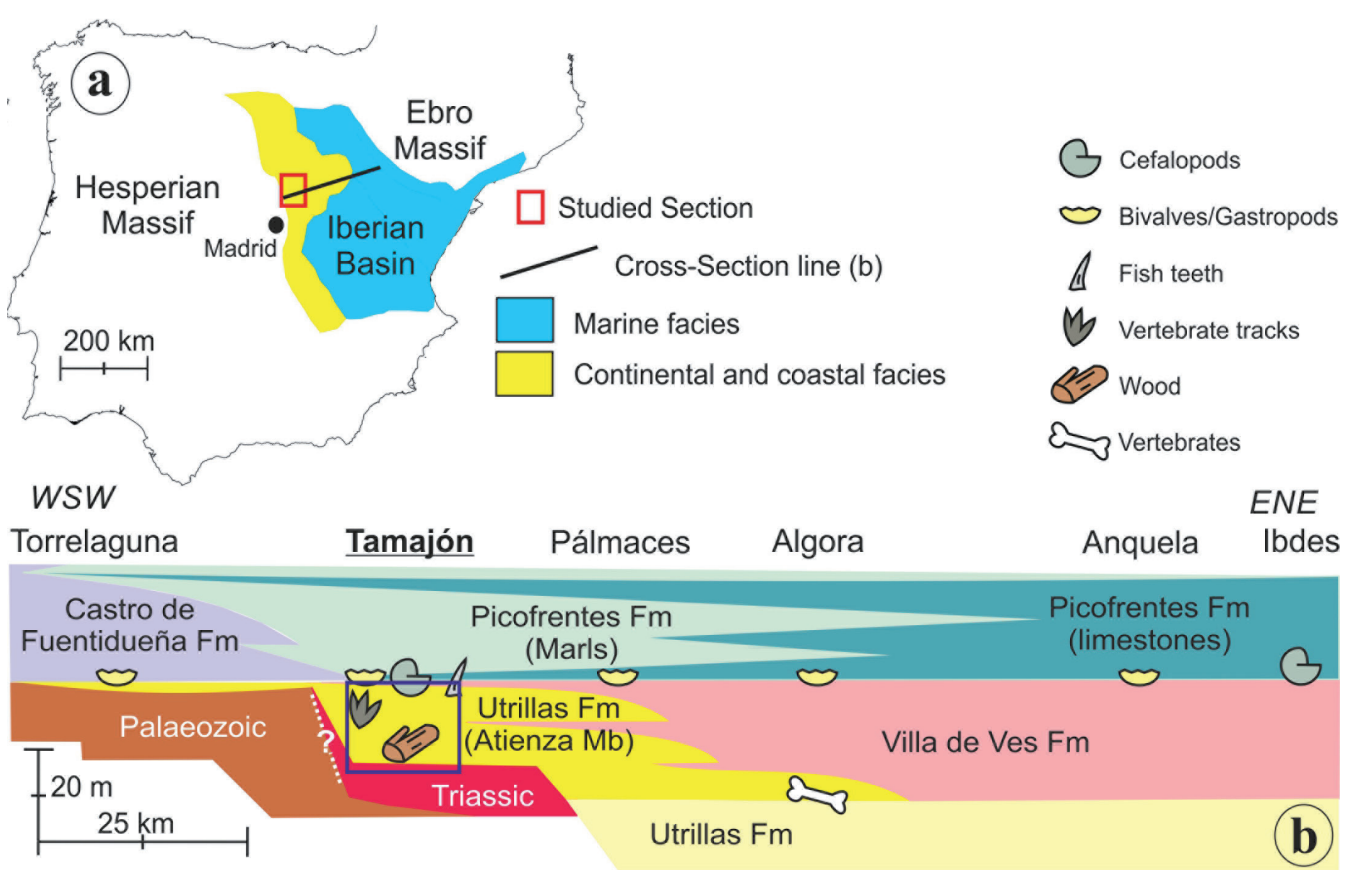

Fig. 1.- a) Late Cenomanian paleogeography of the Iberian Basin, based and modified from Segura et al. (2004); b) Crosssection showing location of the studied outcrop and main stratigraphic units and sections.

Climate modelling suggests a much less pronounced seasonality in the Northern Hemisphere during the Cenomanian than in previous periods (Fluteau et al., 2007). According to these authors, the flooding of vast continental areas of North America and Eurasia, related to the Late Cretaceous sea-level rise, provided warmer and milder summers and increased rainfall in North America and on the margins of the Tethys. Based on their climatic simulations, the Iberian and other Tethyan islands had a tropical humid climate during the Cenomanian (see Fig. 15 in Fluteau et al., 2007).

\section{Methods}

Facies analyses were performed using the guidelines provided by Collinson and Thompson (1982). Studied parameters include lithology, grain-size, texture, sedimentary structures, geometry of the strata, and trace fossils. The various lithofacies were grouped into facies associations on the basis of their temporal-spatial relations. The sedimentological work was completed with the collection of paleocurrent data and the analysis of vertical variability of grain-clast sizes.

Lithofacies were logged with a Jacob stick and complemented with many partial sections and observations throughout an entire area of up to $6 \mathrm{~km}$ long, showing different orientations allowing a complete 3-D study of sedimentary features. The study was combined with the construction of photomosaics in order to recognize the overall lateral and vertical facies variability, and sand body geometry following detailed bedding contacts.

In order to study the mutual relationships between facies and facies associations and the overall depositional architec- ture, an analysis of bounding surfaces was completed. The Tamajón outcrop was selected because its great lateral continuity (about $6 \mathrm{~km}$ long), the presence of different face-outcrop orientations along section and accessibility. Several orders of bounding surfaces have been recognized (Miall, 1985; 1996). The minor order surfaces $\left(1^{\text {st }}\right.$ to $3^{\text {rd }}$-order $)$ are appropriate for facies description (Table 1), and interpretation. The $8^{\text {th }}$ order surfaces, at the base of the different facies associations, represent major sedimentary breaks and/or erosive surfaces; across these surfaces channel architecture and coarser/finer grained facies ratios (mainly sand/mud ratio) are clearly different. $7^{\text {th }}$-order surfaces represent extensive, outcrop-scale, erosive surfaces within facies associations, with local sedimentary interruption. Further work in wider areas, on their lateral extent and regional significance, will help to precise the hierarchy of these higher-rank surfaces. Finally, there are minor erosive surfaces $\left(4^{\text {th }}-6^{\text {th }}\right.$-order $)$ that can be interpreted in relation to single channel and main channel belt system development, which were probably originated by events such as single channel avulsion and changes in the depositional style of the belt systems within a single facies association.

The type of interconnections among facies and the vertical stacking pattern of the facies associations allowed for the recognition of the transgressive trend for the Utrillas Formation as a whole (Fig. 1b).

\section{Facies and facies associations}

Twelve clastic sedimentary facies are recognized in the studied Cenomanian Utrillas Formation (Table 1). These facies are grouped, from base to top, in four facies associa- 


\begin{tabular}{|c|c|c|c|c|}
\hline Facies & Description & $\begin{array}{l}\text { Fossils and } \\
\text { Ichnofossils }\end{array}$ & Suggested processes & Environment \\
\hline $\begin{array}{l}\text { Gm. Massive } \\
\text { conglomerates } \\
\text { and pebbly } \\
\text { sandstone }\end{array}$ & $\begin{array}{l}\text { Cobble to pebble-grade, clast-supported conglomerates. Massive. } \\
\text { Sub-rounded to rounded extrabasinal clasts (quartzite and vein } \\
\text { quartz, minor rock fragments). Poorly sorted, no grading to weak } \\
\text { normal or inverse grading. Lens-shaped beds from decimeters to } \\
\text { meters thick and up to tens of meters wide. Erosional, bases and } \\
\text { sharp tops. }\end{array}$ & Wood remains. & $\begin{array}{l}\text { Rapid gravel deposition from poorly confined flows within } \\
\text { channels, in which massive settling of the sediment load } \\
\text { prevented the development of bedforms. }\end{array}$ & $\begin{array}{l}\text { Channel } \\
\text { mainly in } \\
\text { braided fluvial. }\end{array}$ \\
\hline $\begin{array}{l}\text { Gh, Horizontally } \\
\text { stratified } \\
\text { conglomerate }\end{array}$ & $\begin{array}{l}\text { Clast-supported, horizontally stratified, granule-pebble conglomerate } \\
\text { and coarse sandstone. Horizontal to gently inclined stratification } \\
\left(<10^{\circ}\right) \text { and poor imbrication. Beds extend laterally for tens of metres } \\
\text { and have subplanar, slightly erosional to nonerosional boundaries. } \\
\text { Rare, normal or inverse grading. }\end{array}$ & $\begin{array}{l}\text { Wood } \\
\text { fragments. }\end{array}$ & $\begin{array}{l}\text { Upper-flow regime, plane-bed conditions and deposition on } \\
\text { low-relief longitudinal bars. }\end{array}$ & $\begin{array}{l}\text { Channel } \\
\text { mainly in } \\
\text { braided fluvial. }\end{array}$ \\
\hline $\begin{array}{l}\text { Sc. Cross-bedded } \\
\text { sandstone }\end{array}$ & $\begin{array}{l}\text { Coarse- to medium-grained sandstone and pebbly sandstone; } \\
\text { moderately to well sorted. Medium to very-thick bedded; tabular to } \\
\text { lenticular geometry with flat to concave erosive bases with granule/ } \\
\text { pebble lags; and planar upper surfaces. Planar and trough (minor) } \\
\text { cross-bedding. Reactivation surfaces are common. Large sandy } \\
\text { bodies, channelized morphology with cosets up to } 2 \mathrm{~m} \text { thick. }\end{array}$ & & $\begin{array}{l}\text { Bed-load sedimentation from unidirectional flows as indicated } \\
\text { by the presence of cross-bedding; recording the migration of } \\
\text { dune to bar-scale bedforms Amalgamated channel deposits } \\
\text { common. Channel-bars in multi-story channels prone to rapid } \\
\text { channel avulsion. }\end{array}$ & $\begin{array}{l}\text { Channel in } \\
\text { braided river or } \\
\text { estuarine. }\end{array}$ \\
\hline $\begin{array}{l}\text { Sm. Massive } \\
\text { sandstone }\end{array}$ & $\begin{array}{l}\text { Thick- to thin-bedded, coarse- to fine-grained sandstone. Massive } \\
\text { with scoured bases and flat tops. Thick-bedded massive sandstone } \\
\text { are related to Gh and Sc facies No grading, no stratification, outsized } \\
\text { granule-pebble clasts. Locally, weak horizontal lamination. Related } \\
\text { to ironstones. }\end{array}$ & $\begin{array}{l}\text { Bioturbation. } \\
\text { Wrinkle } \\
\text { structures. }\end{array}$ & $\begin{array}{l}\text { Deposition by hyperconcentrated flows. Rapid settling of sand, } \\
\text { deposited directly from turbulent suspension with insufficient } \\
\text { time for bedform development. The presence of common } \\
\text { burrows suggests large periods without sedimentation allowing } \\
\text { wrinkle development, bioturbation and iron encrusting. }\end{array}$ & $\begin{array}{l}\text { Braided fluvial } \\
\text { or Estuarine. }\end{array}$ \\
\hline $\begin{array}{l}\text { Slp. Large-scale, } \\
\text { planar, cross- } \\
\text { bedded channeled } \\
\text { sandstone }\end{array}$ & $\begin{array}{l}\text { Cross bedded sandstones, pebbly sandstones and minor } \\
\text { conglomerates as lag deposits. Large-scale erosionally based with } \\
\text { channelized geometry. Inclined bedding, planar cross-stratified } \\
\text { in large scale sets (up to } 2-4 \text { m thick), grading upwards to thin to } \\
\text { thick-bedded; tabular or wedge-shaped beds. Reactivation surfaces. } \\
\text { Overall normal grading, mudstone rip-up clasts. Directly related to } \\
\text { Ssc facies. }\end{array}$ & $\begin{array}{l}\text { Bioturbation } \\
\text { (rare). }\end{array}$ & $\begin{array}{l}\text { High-energy and rapid bed-load deposition from unidirectional } \\
\text { currents as indicated by the presence of cross-bedding; } \\
\text { recording the migration of bars. Subaqueous lateral acretion } \\
\text { foresets related to high energy, deep incised channels. }\end{array}$ & $\begin{array}{l}\text { High-energy, } \\
\text { tidally- } \\
\text { influenced } \\
\text { coastal } \\
\text { channel. }\end{array}$ \\
\hline $\begin{array}{l}\text { Ssc. Cross- } \\
\text { bedded sheet } \\
\text { sandstone }\end{array}$ & $\begin{array}{l}\text { Granule to fine-grained sandstone, forming laterally extensive } \\
\text { sheets up to } 4 \mathrm{~m} \text { thick with flat to planar, scoured erosive bases. } \\
\text { Planar cross-bedding with normal grading and superimposed } \\
\text { minor-scale lamination within the cross beds, as rhythmically } \\
\text { interstratified of granule and sandy laminae resulting in decimeter } \\
\text { scale to metre-scale tangential foreset bundles. Reactivation surfaces } \\
\text { common. Herringbone cross bedding. Mudclasts and mud drapes } \\
\text { in the foresets. Water escape structures up to } 0.4 \mathrm{~m} \text { high. Trimodal } \\
\text { palaeocurrent distribution. }\end{array}$ & $\begin{array}{l}\text { Bioturbation } \\
\text { (rare). }\end{array}$ & $\begin{array}{l}\text { Accumulation of small to medium-sized dunes and bars. } \\
\text { Continuous reworking and movement of sand by variable } \\
\text { bidirectional flow regime. Tidal bedding, probably controlled } \\
\text { by semi-diurnal cycles. Suspended sedimentation in mud } \\
\text { drapes during slack water periods. Sediments locally have } \\
\text { undergone liquefaction immediately after sedimentation of the } \\
\text { overlying sandstones; making sediments prone to liquefaction, } \\
\text { developing water escape structures. Palaeocurrents and } \\
\text { herringbone indicate bidirectionality in flow directions. }\end{array}$ & $\begin{array}{l}\text { High-energy } \\
\text { intertidal- } \\
\text { subtidal, } \\
\text { tidally- } \\
\text { influenced } \\
\text { coastal bars. }\end{array}$ \\
\hline $\begin{array}{l}\text { Sr. Rippled } \\
\text { sandstone }\end{array}$ & $\begin{array}{l}\text { Thin bedded, fine- to medium-grained sandstone locally inter bedded } \\
\text { with thin-to-very thin siltstone beds. Sandstone - current rippled } \\
\text { or small-scale planar cross bedded; Siltstone - thickly laminated to } \\
\text { rippled; exposures are bound and internally partitioned by channel } \\
\text { scours. Overall channeled geometry. Related to Ssc and Slp facies. }\end{array}$ & & $\begin{array}{l}\text { Deposition by weak unidirectional subaqueous flows under } \\
\text { lower-flow regime conditions. In-channel sedimentation based } \\
\text { on the overall channeled geometry. Final channel infill. }\end{array}$ & $\begin{array}{l}\text { Tidally- } \\
\text { influenced, } \\
\text { coastal } \\
\text { channel. }\end{array}$ \\
\hline $\begin{array}{l}\text { Ssb. burrowed } \\
\text { sandstones }\end{array}$ & $\begin{array}{l}\text { Fine- to coarse-grained sandstones. Sharp bases. Massive } \\
\text { probably due to bioturbation, which largely obliterated the original } \\
\text { sedimentary structures. Size of trace fossils highly variable and } \\
\text { common, small burrows. }\end{array}$ & $\begin{array}{l}\text { Burrowing } \\
\text { common, } \\
\text { mainly } \\
\text { Planolites- and } \\
\text { Teichichnus- } \\
\text { Type traces }\end{array}$ & $\begin{array}{l}\text { The type and degree of bioturbation suggests a marine } \\
\text { environment and indicates that sedimentation rate was } \\
\text { relatively low at times, allowing burrowing organisms enough } \\
\text { time to keep pace with sedimentation and rework any sediment } \\
\text { deposited. }\end{array}$ & $\begin{array}{l}\text { Offshore } \\
\text { marine. }\end{array}$ \\
\hline $\begin{array}{l}\text { Ihs. Inclined } \\
\text { heterolithic strata }\end{array}$ & $\begin{array}{l}\text { Thin- to medium-bedded sandstones interbedded upwards with } \\
\text { mudstones and minor siltstones in inclined beds. The inclined beds } \\
\text { are bounded by erosional surfaces; these surfaces are mantled by } \\
\text { sandy sediments towards the basal part, and become heterolithic } \\
\text { in their upper part. Sandstones are massive or small-scale planar } \\
\text { cross bedded; scours locally below sandstone beds. Mudstones and } \\
\text { siltstones are thickly laminated. These Ihs sediments are clearly } \\
\text { erosive over underlying sediments; beds have a depositional dip of } \\
\text { approximately } 10-20^{\circ} \text {, being parallel to the basal erosive surface. } \\
\text { Inclined units are separated by inclined surfaces indicative of non- } \\
\text { deposition or erosion with thin ferruginous sandstones. }\end{array}$ & & $\begin{array}{l}\text { Meandering channel with point bar development. The sandy } \\
\text { basal portion represent the lower point bar, and the heterolithic } \\
\text { upper portion represents the upper point bar deposits. The } \\
\text { final mudstones and siltstones infill represent clay plugs in } \\
\text { abandoned channels; sedimentation is controlled by mud } \\
\text { settling during long periods in which silty layers result from } \\
\text { overbank floods. }\end{array}$ & $\begin{array}{l}\text { Estuarine. } \\
\text { River- } \\
\text { dominated, } \\
\text { mixed river } \\
\text { and tide, or } \\
\text { tide-dominated } \\
\text { meandering } \\
\text { channels. }\end{array}$ \\
\hline $\begin{array}{l}\text { SsM, Siltstone } \\
\text { and mudstone }\end{array}$ & $\begin{array}{l}\text { Massive to laminated mudstone and siltstone. Dominantly massive } \\
\text { but weakly laminated in some places. In-channel deposits with } \\
\text { lenticular trend. }\end{array}$ & $\begin{array}{l}\text { Burrowing } \\
\text { (rare). }\end{array}$ & $\begin{array}{l}\text { Deposited from suspension or variable very low energy } \\
\text { deposition, within a quiet, low energy water body, final infill of } \\
\text { estuarine or tidally-influenced channels (mud plug). }\end{array}$ & $\begin{array}{l}\text { Estuarine } \\
\text { and tidally } \\
\text { influenced } \\
\text { coastal } \\
\text { channels. }\end{array}$ \\
\hline $\begin{array}{l}\text { Mm. Massive } \\
\text { mudstone }\end{array}$ & $\begin{array}{l}\text { Mudstones. Massive; occasionally thinly laminated and diffuse } \\
\text { mottling. Occasionally lenticular channel final infill. Related to } \\
\text { many different other facies. The exposure of this facies is usually } \\
\text { poor due to the style of weathering, being usually covered by talus } \\
\text { scree deposits, which impedes detailed observations. }\end{array}$ & $\begin{array}{l}\text { Burrowing } \\
\text { (absent to } \\
\text { common). }\end{array}$ & $\begin{array}{l}\text { Primary depositional processes related to the settlement of finer } \\
\text { sediments carried in suspension by water flows in different } \\
\text { environments: Overbank flood deposits on a flood plain. } \\
\text { Dominance of fine-grained facies in marine environments; in } \\
\text { this case bioturbation is more common representing the activity } \\
\text { of substrate-feeding organisms. }\end{array}$ & $\begin{array}{l}\text { Estuarine. } \\
\text { Flood plain. } \\
\text { Low-energy } \\
\text { offshore } \\
\text { environment. }\end{array}$ \\
\hline $\begin{array}{l}\text { Fe. Ironstones, } \\
\text { ferruginous } \\
\text { crusts }\end{array}$ & $\begin{array}{l}\text { Ferruginous, thin-bedded, massive or laminated sandstones. Muddy, } \\
\text { red iron mm crusts at consolidated top of the beds and base of } \\
\text { channels, and nucleated around trace fossils as burrow coatings. }\end{array}$ & $\begin{array}{l}\text { Vertebrate } \\
\text { tracks. Wrinkle } \\
\text { structures. } \\
\text { Burrows. }\end{array}$ & $\begin{array}{l}\text { Sedimentary breaks at top of sedimentary units or related } \\
\text { non-sedimentation surfaces. Synsedimentary iron precipitation. } \\
\text { Low sedimentation rates. }\end{array}$ & $\begin{array}{l}\text { Several } \\
\text { environments. }\end{array}$ \\
\hline
\end{tabular}

Table 1.- Sedimentary facies and their interpretations distinguished in the present study. 
tions (FA 1 to FA4) that are assignable to distinct depositional environments (braided fluvial, FA1; tidal-fluvial estuarine, FA2; high-energy, tidally coastal bars and channels, FA3; and offshore, FA4). The distribution of the different facies recognized is summarized in Table 1, figures 2 to 7 , and discussed below.

\subsection{Facies Association 1 (FA1): Braided fluvial (Facies Gm, Gh, Sc, Sm, Fe; Table 1)}

\section{Description}

Dark brown or reddish sandy facies are dominant, except in the basal part of the association, where conglomerate facies are discontinuously found, but common (Fig. 2a and b). The most common facies are cross-bedded and massive sands ( $\mathrm{Sc}$ and Sm, Fig. 2c and d) and, at the base, clast-supported stratified (Gh, Fig. 2a and b) and massive conglomerates (Gm, Fig. $2 a$ and $b$ ). The coarse fraction is well to poorly sorted, the variation of which generally defines the planar stratification or cross-bedding of all these facies. Lags and reactivation surfaces are common. Wood fragments are abundant on lags, and in some basal beds (fragments up to $15 \mathrm{~cm}$ long are preserved; Fig. 2d). Minor facies are very thin millimetric, red ferruginous, muddy tops ( $\mathrm{Fe}$ ) with wrinkle marks and bioturbation. There is an overall fining upwards trend, from coarse gravel to sandstones, pebbly sandstone being common.

This facies association is composed of channel-shaped conglomerates and sandstones. There are some differences in the aspect of the channel-shaped bodies at the lower and at the upper part of this association. Channels 5-20 m wide and 1-2 m thick, crosscutting one another laterally, are the most abundant architectural element of at the base of FA1 (1.1 in Fig. 8). Channels in the upper part of FA1 are made up of individual channels stacked together to form wider, channel complexes (1.2 in Fig. 8), which slightly cut into underlying strata. Individual channels are $2-5 \mathrm{~m}$ thick and 40 to $100 \mathrm{~m}$ wide. Inclined, slightly erosive planar surfaces, rather than concave channelized surfaces, are common.

\section{Interpretation}

The channeled lithosomes of this facies association are stacked to form multi-lateral channel complexes in a braided fluvial environment. Coarse-grained facies show evidences of strong, erosive channelized flows, as indicated by the erosive bases and the coarse-grained facies (facies Gh, Gm, Sc, and $\mathrm{Sm}$ ). Units of Gh represent upper plane-bed sedimenta-
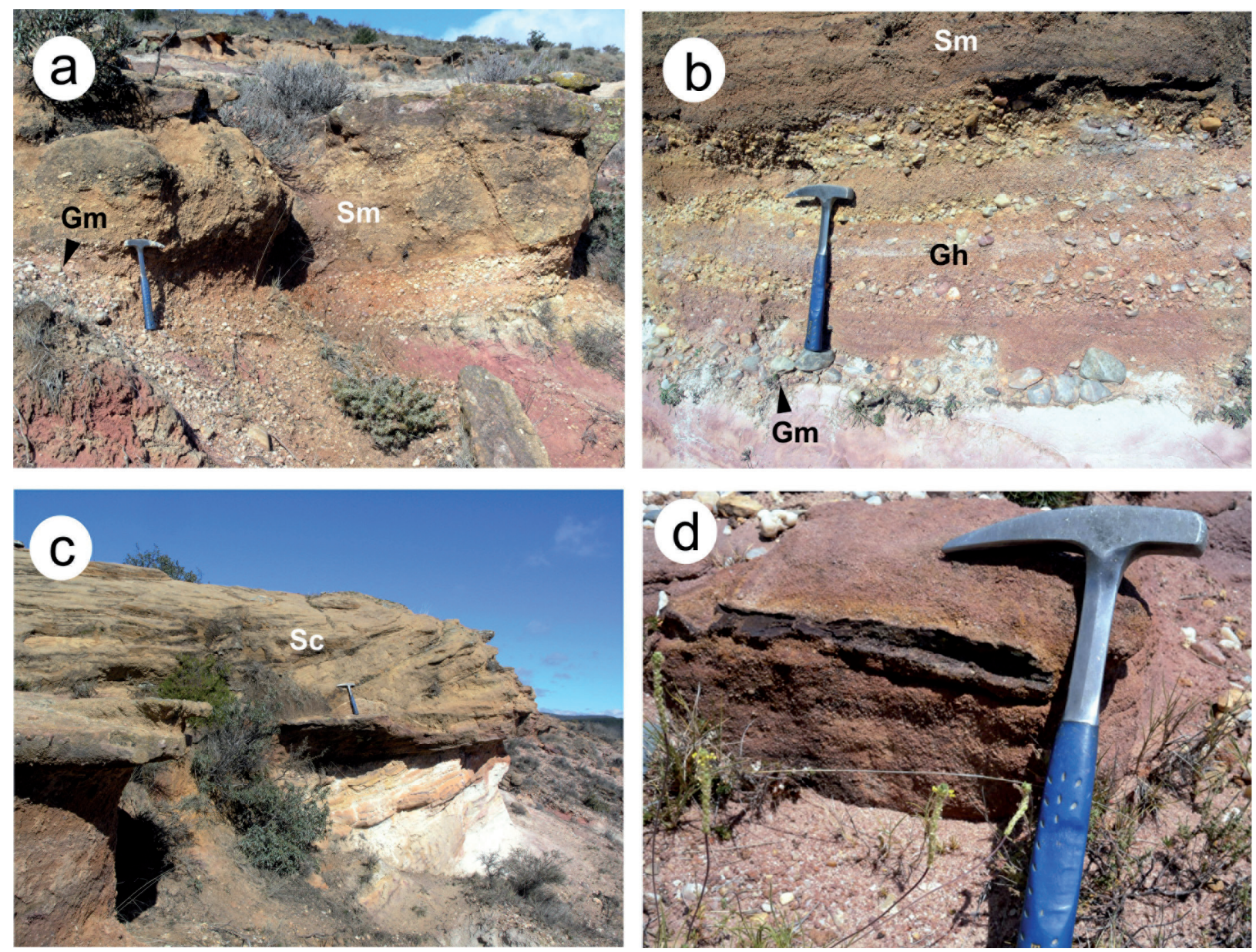

Fig. 2.- Main facies of FA1 (see Table 1 for a detailed description). a and b) Gm, Gh and Sm facies interpreted as in channels sediments deposited in a braided environment, at the base of the Utrillas Formation; the underlying red sandstones are Triassic sandstones. c) Sc facies representing bar sediments in braided channel. d) Very large wood fragment in Sm facies. Hammer for scale is $32 \mathrm{~cm}$ long in all cases. 
tion in relation to the growth and development low-relief longitudinal bars, implying rapid flow and (or) shallow depth; the abundance of gravels indicates high flow competence at the base of the succession. The predominance of cross-bedding in facies Sc indicates the migration and accumulation of dunes by tractional flows within channel bottoms (Fig. 2c). Gm and Sm facies represent rapid gravel or sand deposition directly from turbulent suspension within channels, with insufficient time for bedform development. The thicknesses of the different facies suggest shallow channels filled during waning flows, implying that high flow events were probably intermittent. The high numbers of channels record repeated cut-and-fill processes (Collinson and Thompson, 1982) within a long-lived, large scale channelled system where repeated avulsions were common.

The location of this facies at the base (unconformable) of the Cretaceous sediments, the presence of wood fragments (Fig. 2d), and sudden grain-size changes support sedimentation in braided fluvial settings. The presence of ventifacts suggests, at least partially, re-elaboration of underlying Triassic conglomerates (Segura and Elorza, 2013). In this sense, it is important to point out that only a very small fraction of the clasts are ventifacts; being the vast majority, however, rounded or subrounded clasts of the same lithology and size than the ventifacts.

Due to the predominance of channelized deposits and the absence of lateral flood plain deposits, FA1 represents deposition of sands and gravels as channel-bars in multi-story channels, which are usually characterized by a low sinuosity pattern (Benvenuti and Del Conte, 2013). These features and the style of sedimentation suggest deposition by channels dominated by stream floods in a low-sinuosity channelized environment, within a braided fluvial system (Cant and Walker, 1978) or a braidplain prone to rapid channel avulsion (e.g., Ashworth et al., 2007) (Fig. 9a). Available palaeocurrent data suggest that sediment was supplied from the west and southwest, in agreement with source area location (Fig. 1a). Due to the known paleogeography (Fig. 1a) of the continental-basin transition in the Iberian Basin (García-Hidalgo et al., 2007), the sedimentary environment probably consisted of a longitudinal braided paleovalley related to a punctual source area from the hinterland (Fig. 9a).

\subsection{Facies Association 2 (FA2): Tidal-fluvial (Estuarine) (Facies Sc, Sm, Ihs, SsM, Mm, Fe; Table 1)}

\section{Description}

FA2 is characterized by near-equal proportions of coarsegrained $(\mathrm{Sc}$, and $\mathrm{Sm})$ and fine-grained facies ( $\mathrm{SsM}$ and $\mathrm{Mm}$ ). The geometry of sandstone beds is mainly lenticular, channeled, with high erosive bases; but locally, they also form small and thin (up to $0.8 \mathrm{~m}$ thick) tabular to lateral accretion, sigmoidal sets, with relatively low erosional bases, that are laterally continuous for several tens of meters. Both sandstone channels and beds pinch out laterally into muddy sediments. Maximum grain size of sandy facies is, however, smaller than in FA1. Channelized elements extend tens of meters wide. The most distinctive feature of this association is the presence of isolated, inclined heterolithic lateral accretion strata (Ihs; Thomas et al., 1987). They are up to $3 \mathrm{~m}$ thick and about $50 \mathrm{~m}$ wide, being composed of alternating sandstones, siltstones and mudstones with a final muddy infill of the channel (Fig. 3a). The large-scale inclined beds are bounded below and above by two erosional surfaces; these surfaces are mantled by sandy sediments towards the basal part, and become heterolithic in their upper part. Fine-grained mudstones and siltstones, however, are more common than in the underlying association, being the only facies present in some areas. In some points a relatively thick, red ferruginous mudstone is found at top of the association (Fig. 3b).

FA2 represents a change both in sand/mud ratio and in channel architecture. Flood-plain elements (Fig. 3b) are almost as common as channelized ones (Fig. 3a) in this association (sand/mud ratio is approximately equal); but as this association is relatively thin (up to $5 \mathrm{~m}$ thick), it can be entirely sandy or muddy at local points of the section (Fig. 3a, b).

\section{Interpretation}

Channeled deposits have a clearly incised base and exhibit abrupt pinch-outs with clear cut-banks (Fig. 3a); they rarely connect to the tabular sandstones laterally. Inclined heterolithic stratification (Ihs) is the dominant geometry of channel infill (Fig. 3a); these features are clearly seen when outcrop change in orientation to a NE-SW trend, suggesting that outcrop orientation probably bias some sedimentary observations. These inclined beds and surfaces are interpreted to have arisen via dominantly lateral accretion. They are usually considered as originated by meandering channels with sedimentation in the inside part of the meander, related to the fluvial-tidal transition (Dalrymple and Choi, 2007; Choi, 2010; Johnson and Dashtgard, 2014). These lateral-accretion bedding are formed by the migration of attached and point bars, and they are erosively based, because of the migration of the basal part of the channel. The resulting displacement of the entire channel generates the lateral-accretion deposits characteristics of the Ihs. The basal sandy beds represent the lower point bar deposits; meanwhile, Ihs truly characterizes upper point bar deposits. Finally, homogeneous or laminated mudstones are often recognized as abandoned channel ("mud plug") sediments (Thomas et al., 1987).

On the other hand, tabular sandstones are considered overbank deposits, being largely attributed to rapid deposition of sand from unconfined flows on the floodplain in crevasse splays and channels (e.g., Shiers et al., 2014).

Point bars represent a typical feature of meandering rivers (Bridge, 2006) and tidally influenced meandering channels. (Thomas et al., 1987; Sisulak and Dashtgard 2012; Shiers et al., 2014). Modern examples of Ihs are recorded from river- 

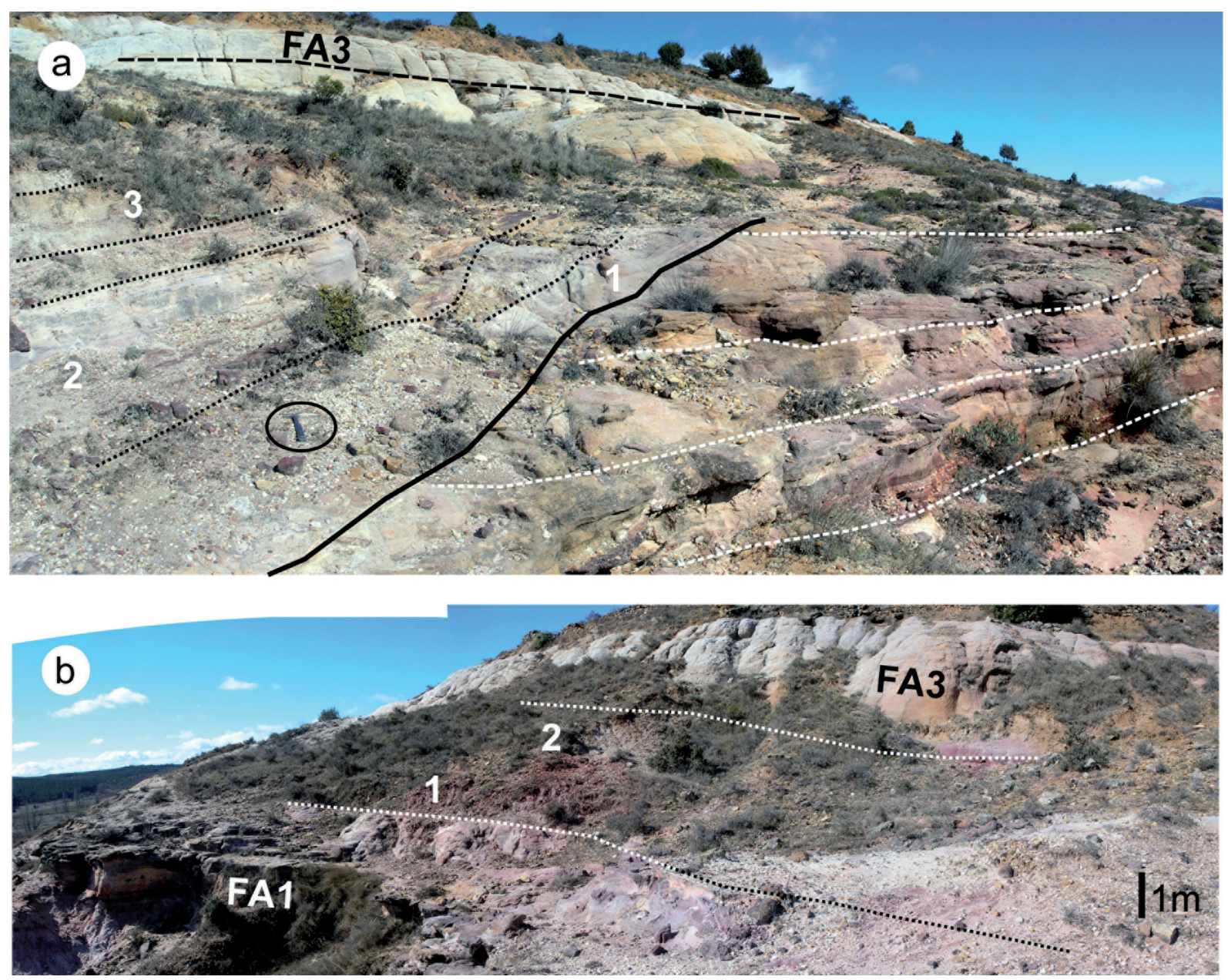

Fig. 3.- Main facies of FA2 (see Table 1 for a detailed description). a) view of Inclined heterolithic stratification (Ihs facies) in a channel with sandy beds (1) parallel to the basal erosive surface, sandy ferruginous crusts (2) and final muddy and silty (3, SsM facies) infill, interpreted as an estuarine channel deposit; hammer (encircled) is $32 \mathrm{~cm}$ long. b) Photocomposition showing purple (1, base) and whitish (2, top) mudstones (Mm facies) interpreted as flood-plain elements related laterally to the main channels (showed in Fig. 3a).

dominated (Smith et al., 2009), mixed river and tide (Sisulak and Dashtgard, 2012), and tide-dominated channels (e.g., Dalrymple and Choi, 2007; Choi, 2010). This facies association is thus related to tidally-influenced fluvial deposits in an estuarine environment, where the alternating sandstone and finer sediment beds are attributed to alternations in the energy of the system (Johnson and Dashtgard, 2014).

\subsection{Facies association 3 (FA3): High energy, tidally coastal bars and channels (Facies Slp, Ssc, Sr, SsM, Mm, Fe; Table 1)}

\section{Description}

This association consists predominantly of sandy facies (Ssc, Slp, Sr; Fig. 4a to f and Fig. 5); minor finer-grained facies ( $\mathrm{SsM}$ and $\mathrm{Mm}$ ) and ferruginous crusts $(\mathrm{Fe})$ are also present. Main facies correspond to erosively-based, sheet sandstone bodies (Ssc; Fig. 4a to c). These sheet sandstones mostly comprise planar, cross-stratified sandstones. Internal erosional bounding surfaces are less than a few decimetres in relief and extend for less than several tens to hundred me- ters (Fig. 5b); quartz and quartzite gravel lags are commonly found here (Fig. 4a). Herringbone cross stratification (Fig. $4 \mathrm{~b}$ ), tidal bundles and mud drapes (Fig. 4c) are common in the sheet sandstones. Ichnodiversitiy is low and bioturbation is reduced or even absent.

FA3 is also characterized by the presence of large, Ushaped, channel-shaped bodies with basal erosive surfaces. These channel-shaped lithosomes are tens of meters wide and up to 5-6 m deep (Fig. 5). The channel fills are mainly composed of a single set of large-scale cross-bedding (Slp; Fig. 5a). Sets are usually $20 \mathrm{~cm}$ up to $4 \mathrm{~m}$ thick, formed by avalanching on the foresets of sandy unit bars. Coarse to pebbly-sandstones with normally graded foresets, presenting centimetre-thick planar to tangential cross-bedding, are very common (Fig. 5a).

These cross-bedded sands may entirely fill up the channel (Fig. 5a). In other cases, however, final channel fill may be either rippled sandstones (Sr; Fig. 4d) or, more frequently, fine-grained facies, which are mostly composed of laminated siltstones and mudstones or massive mudstones (SsM and 

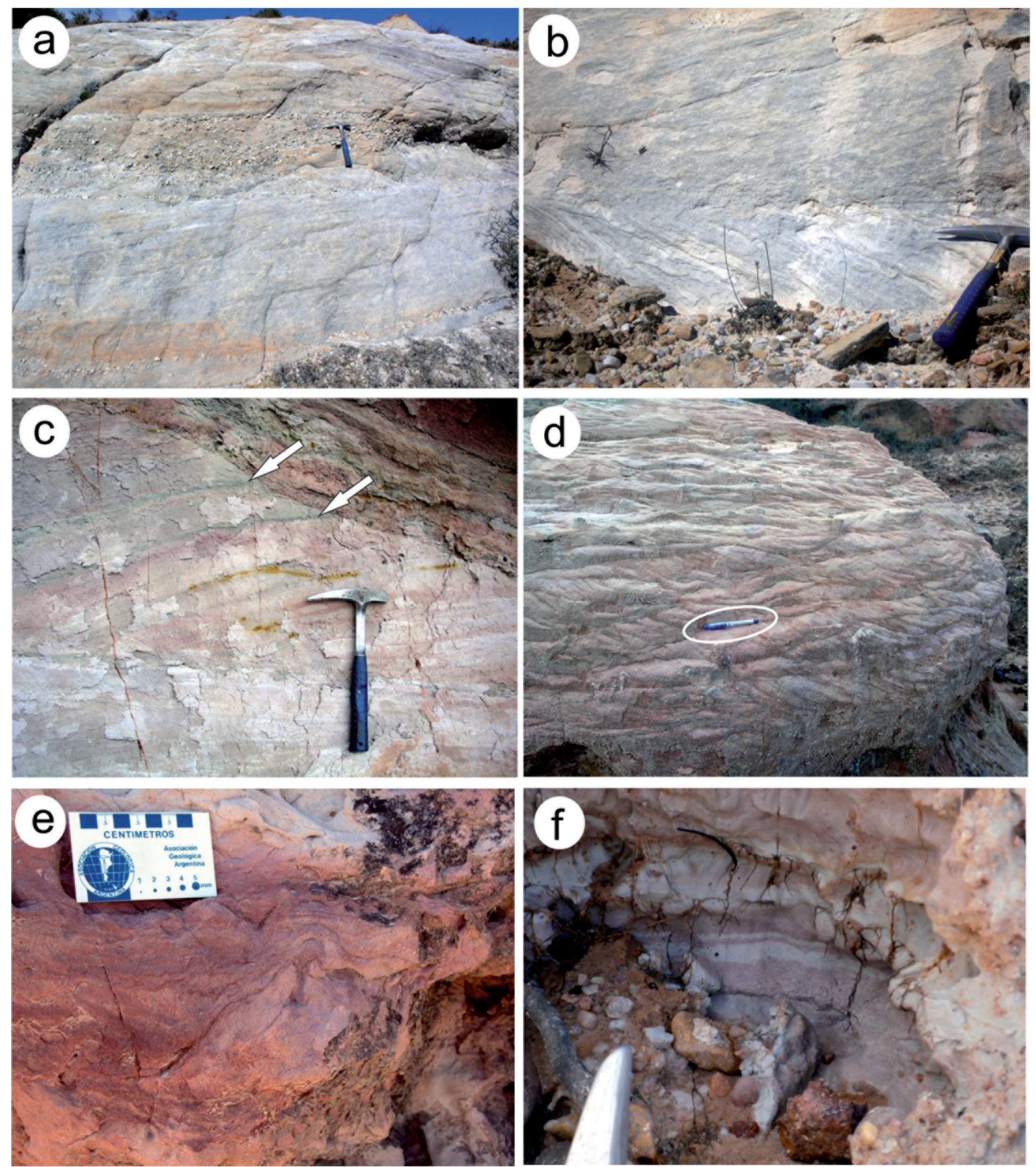

Fig. 4.- Main facies of FA3 (see Table 1 for a detailed description). a) Cross-bedded Ssc facies with; hammer for scale is $32 \mathrm{~cm}$ long (as in $\mathrm{b}$ and c). b) Ssc facies with herringbone cross bedding characteristic of tidal facies. c) Ssc facies with green mud drapes in the foresets (arrows), also typical of tidal environments. d) Sr facies representing the final infill of a sandy channel; pen for scale is 13.5 $\mathrm{cm}$ long. e) water-scape structures in Ssc facies suggesting rapid sedimentation. f) Laminated mudstones and siltstones (SsM facies) representing the final muddy infill of a channel (mud plug); visible hammer tip is $4 \mathrm{~cm}$ long.

Mm; Figs. 4e and 5b). No bioturbation was observed within these fine-grained deposits (SsM or Mm).

Gravels as very thin deposits or as lags are common overlying the large erosional bounding surfaces that form the bases of channel-fill units (Fig. 5). A peculiar and unusual feature of these surfaces is that they are related to the development of ferruginous crusts ( $\mathrm{Fe}$ facies, Fig. 5a; see also section 5.4 and Fig. 11). These ferruginous surfaces are concave-up or inclined surfaces within the channel (Fig. 5a and 11d). They do not line, however, the entire bottom of the channel, being located only in its inactive part. Besides, crusts can be traced out of the channel, on their relatively flat margins, and extend laterally throughout the entire outcrop, for more than thousands of meters, separating tabular sheets bodies (Fig. 11d), suggesting a short, related period of non-deposition. The presence of sporadic bioturbation in the underlying sandstone layers is marked by the reddish sandy infill of the burrows (Fig. 11e); wrinkle marks and vertebrate tracks (mainly 

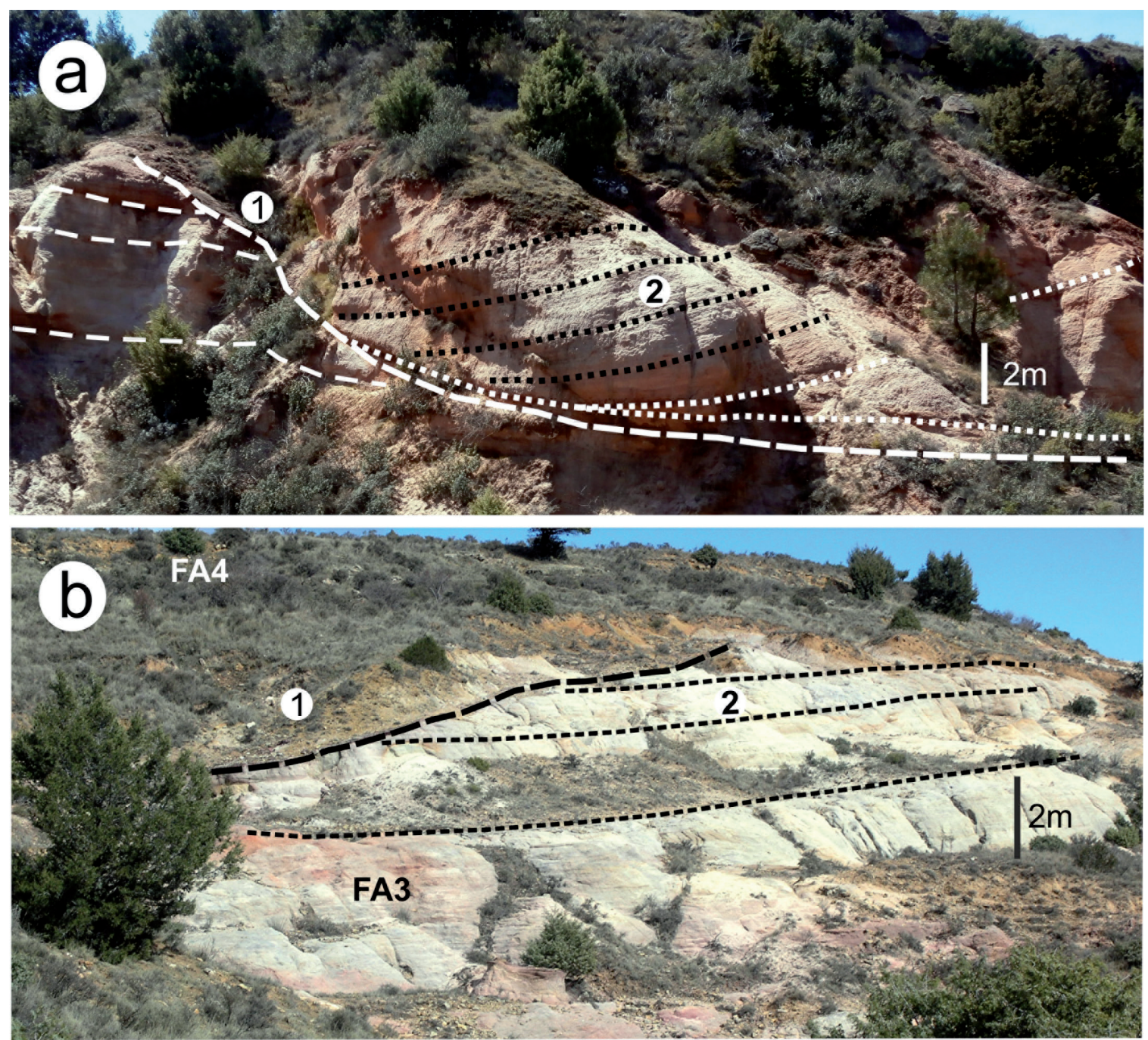

Fig. 5.- Large erosive surfaces and channels in FA3. a) sandy-infilled channel with a large scale, single set of cross bedding (2); the basal bed is a thin, ferruginous sandy level ( 1, left). b) muddy-infilled channel (1) eroded on sheet sandstones (2, Ssc facies); the base of the channel is a conglomeratic lag with ferruginous crust development.

crocodile tracks and fish traces) are locally found and related to Fe facies (Fig. 11c and f).

Mud intraclasts and water scape structures (Fig. 4e) within Slp and Ssc facies are locally found. Palaeocurrents data, mainly from tabular bedforms of relatively thick sets in both sheet sandstones and channels, present three main orientations (tridirectional pattern; E, W and SW; Fig. 6), with a relatively high degree of dispersion.

\section{Interpretation}

Predominant facies consist of lateral extensive sheet sands (Ssc), which point to sedimentation in high-energy, intertidalsubtidal coastal environment, with complex shifting and rapid accumulation of dunes in distributary mouth bars separated by distributary channels (Facies Slp). The size of the sediments, types and sizes of sedimentary structures, and overall lack of fine-grained material suggest relatively continual reworking of sediment by high-energy currents. The implications of the different styles of cross-bedding, identified in this association, are discussed in section 5.3. The presence of low-sinuosity braided channels is suggested by the coarse grain size and sandy nature of the in-channel deposits (Slp), together with the lack of inclined heterolithic stratification. Evidence of tidal process is recorded by the presence of a tridirectional paleocurrent pattern in the sheet and channel deposits (reflecting the complex networks of tidal channels and bars), and herringbone cross stratification, tidal bundles and mud drapes in the sheet sandstones; features usually considered as typical of tidal bars (Darlymple, 1992; Willis, 2005; Olariu et al., 2012). Given the known paleogeography, palaeocurrent directions towards the E probably reflected flood flows; meanwhile, directions towards $\mathrm{W}$ and SW reflected ebb flows, with the ebb directions being dominant (Fig. 6). Rapid sand accumulation is shown by the presence of water escape structures and thus, sediments must have undergone liquefaction immediately after sedimentation of the overlying sandstones. Extremely low ichnodiversitiy and reduced, or even absent bioturbation suggest that these facies were periodically influenced by freshwater discharge. 


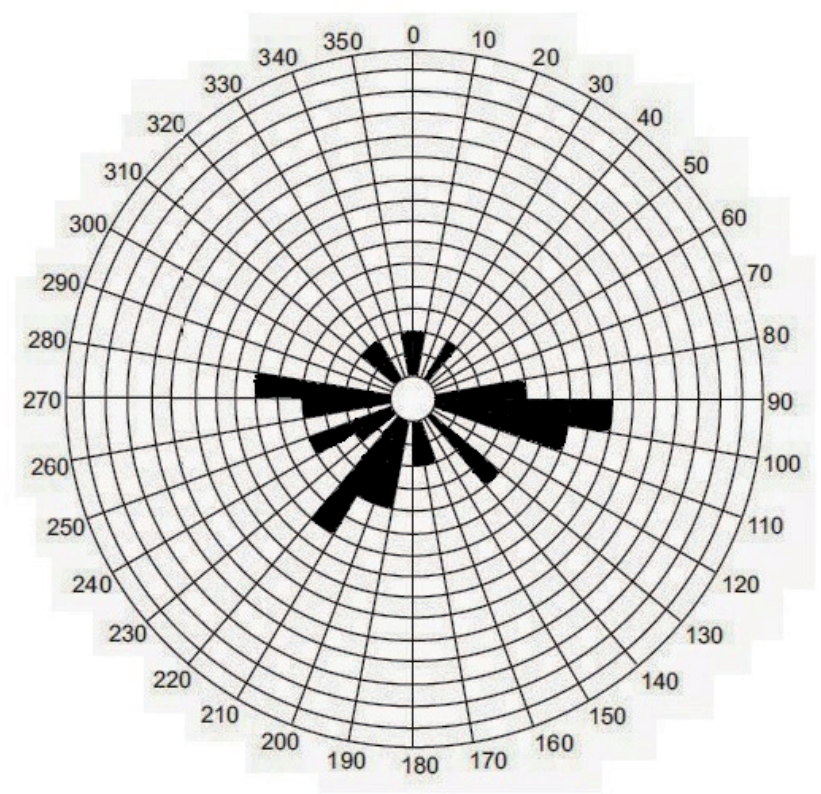

Fig. 6.- Rose diagram showing 62 palaeocurrent measures of planar cross bedding in Slp and Ssc facies in FA3. There is a wide dispersion with three main maxima. E directions probably reflected flood directions in a tidal environment, based on the paleogeography of the Iberian basin (see Fig. 1); W and SW directions probably reflected ebb floods.

Facies related to the final channel infills may be currentripple cross-laminated sandstone (Fig. 4d), but laminated silty mudstone are also common (Fig. 4f); no bioturbation was observed in these muddy deposits. The common presence of channel-lining sandstone related to iron crust development, and wrinkle and vertebrate (crocodile and fish) tracks in some parts of the channels, but not along the entire channel, suggests that they were originated in a subaqueous environment (see section 5.4). These parts of the channels were neither an active sedimentary area nor an erosive one; they were temporary abandonment, with the channel only rarely emergent. The final laminated mudstone infill (Fig. 4f), suggests a gradual rather than an abrupt final abandonment.

The style of sedimentation and sedimentary features suggest sedimentation in tide-influenced coastal areas and/or estuaries (Fig. 9c), where sandy mouth bars and channels have been widely described, both in modern (e.g., Dalrymple et al., 1990; Fenies and Tastet, 1998; Hori et al., 2002; Dalrymple et al., 2003), and ancient examples (Harris, 1988; Mellere, 1994; Schwartz and Graham, 2015).

\subsection{Facies association 4 (FA4): Offshore siliciclastic (Facies Mm, Ssb; Table 1)}

\section{Description}

FA3 grade upwards to FA4 with a gradational, but rapid, transition (Fig. 7a). The exposures of this association are usually poor due to the style of weathering, being usually covered by talus scree deposits, which impedes detailed obser- vations. It is mainly composed of massive mudstones (Fig. 7a), grading laterally to non-channelled massive or burrowed sandstones (Ssb) (Fig. 7b). Bedding is usually discontinuous and unclear; being the sands laterally continuous for hundreds of meters and having subplanar, nonerosional boundaries. In general, sandstones and mudstones of this facies association lack sedimentary structures; the main feature is the local presence of bioturbation (mainly Planolites- and Teichichnus-types).

\section{Interpretation}

Thick and extensive muddy units reflect the dominance of settlement of finer sediments from suspension, suggesting a low-energy environment. The wider lateral extension and the dominance of mudstones, with the absence of tractive sedimentary structures and channels in the sandstones, together with the presence of bioturbation suggest, in opposition to the underlying association, deposition under open, shallow-marine conditions in an offshore siliciclastic setting (Fig. 9d) (e.g., Heinberg and Birkelund, 1984). In this case bioturbation is more common than in underlying facies associations, representing the activity of substrate-feeding organisms.

\section{Discussion}

\subsection{Depositional architecture}

The Cenomanian clastic wedges of the Utrillas Formation were deposited during a major transgressive period at the Late Cretaceous (Gil et al., 2004); the studied sediments show a long term retrogradational trend (Fig. 1b) emphasized by its depositional architecture. The overall upward-fining succession shows a rapid up-section change from higher energy, braided deposits, characterized by the coarse-grained (conglomerate-sandstone) facies, to estuarine first and to tide-influenced sedimentation then and finally to muddy-rich offshore facies as shown in the stacking of the different facies associations (Figs. 8, 9).

The basal surface of the studied succession is a major erosive surface (and a cartographic unconformity) at the base of the late Cretaceous sediments (Fig. 8). No traces of any paleosol developed on the underlying Triassic sediments suggest, at least, an erosion period previous to the onset of Cretaceous sedimentation. The basal associations (FA1 and FA2) are confined to a several thousand meters wide area $(2-3 \mathrm{~km}$ along-strike width), and representing an up to 25 -meter thick unit that laterally wedge out, being FA3 resting locally on the underlying Triassic sediments (Fig. 8). Cretaceous basal incision on the Triassic sediments, however, is apparently slight. The lateral disappearance (pinch out) of the basal Cretaceous sediments suggests that this association probably represents the infill of a wide valley on a very gentle, inherited palaeorelief (Fig. 8). 

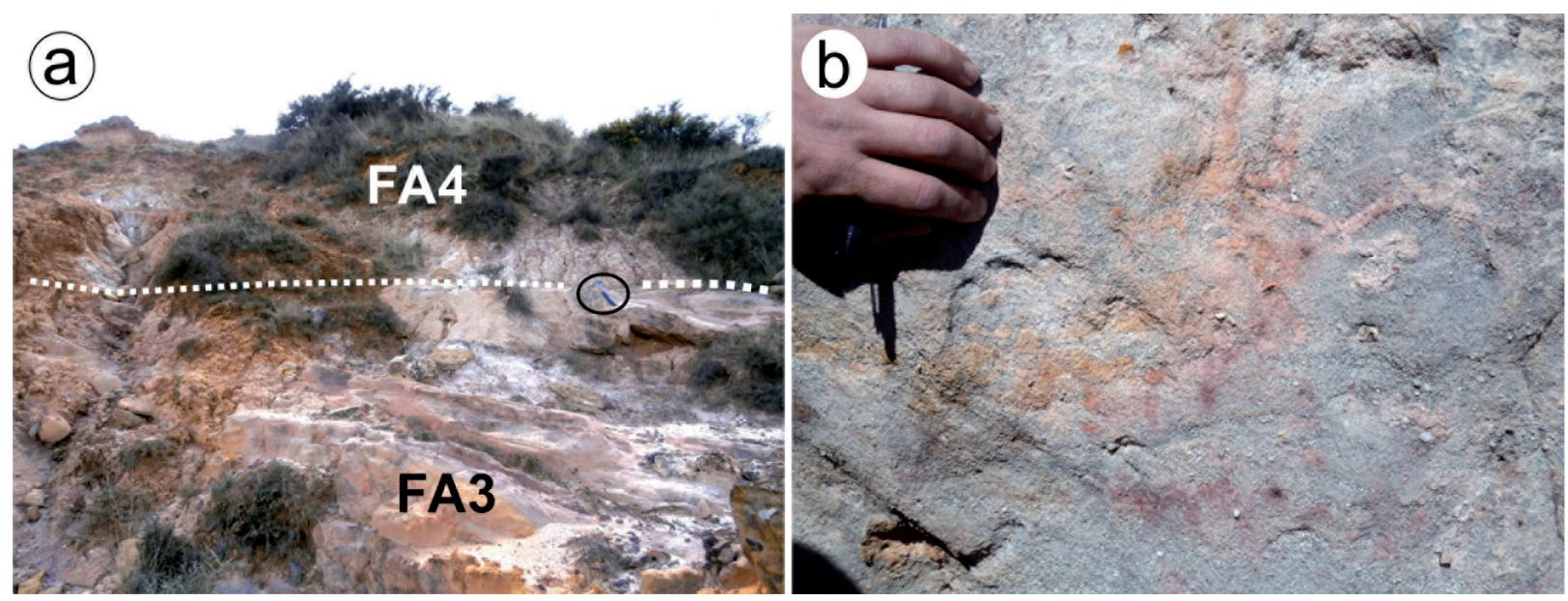

Fig. 7.- Main facies in FA4. a) Massive mudstones (Mn facies), at the upper part of the figure, are the dominant facies in this association; hammer encircled for scale. b) Massive sandstones (Ssb facies), interpreted as marine, offshore sediments.

Multiple, laterally nested channel cuts at the lower part of FA1 (1.1 in Fig. 8) represent common episodes of cut-andfill, probably at high discharge, and then deposit sediments on the channel bed during and after subsequent waning flows. The dominant lateral shifting and the size of channels suggest channel migration probably due to fluctuations in discharge in a braided multi-channel belt system (Fig. 9a). The bedforms preserved in the nested channel fills reflect thus mainly basal channel-fill processes. $1^{\text {st }}$ - through $3^{\text {rd }}$ - order surfaces bounded by $4^{\text {th }}$-order nested channel cuts record nested channel filling by bedform and bar migration processes.

Based on $6^{\text {th }}$ to $7^{\text {th }}$-order bounding surfaces, channels were longer and wider in the upper part of FA1 (1.2 in Fig. 8). Low relief on $2^{\text {nd }}$ - and $3^{\text {rd }}$-order surfaces within these channels argue that these bedforms tended to fill channel as component of sand sheets and low-relief in-channel bars. The absence of fining upward sequences suggests energy maintenance in relatively high levels as infilling of the channel progressed. The presence of inclined bounding surfaces might also suggests the presence of lateral accretion geometry of the channel fill, but this is probably more apparent than real and related to channel belt aggradation.

A major bounding surface ( $8^{\text {th }}$-order) occurred at the top of FA1 (Fig. 3b). It is represented by the top of a relatively thick ferruginous crust suggesting a period of sedimentary interruption. Locally, channels at the base of the overlying FA2 erode this surface and cut deeply into the underlying FA1 sandstones (Fig. 3a).

The change in channel architecture (with Ihs development; 2.1 in Fig. 8) and the presence of larger floodplain areas (2.2 in Fig. 8), probably suggest a progressive shallowing, broadening and downstream channel network termination, regarding the underlying braided-fluvial environment (FA1), and a transition probably to a tidal-fluvial estuarine area with a low topographic gradient (Fig. 9b). The smaller grain size regarding the underlying association also suggests smaller overall transport energy. Estuaries frequently show a seaward-fining trend in their fluvially dominated areas, and a landward-fining trend in their seaward parts (Dalrymple and Choi, 2007). Besides, channels are common in tidal environments, with a preponderance of laterally accreting channel margins (Ihs common).

Another bounding surface with a thick ferruginous crust is located at the top of flood plain deposits of FA2 (Fig. 3b), representing the top of FA2 in these proximal areas. This crust is locally eroded in relation to the base of the overlying FA3.

A major change in facies architecture occurs at FA3. There is a major change both in sand composition (ferruginous, iron cemented, brownish sands in FA1-FA2 change to whitish, caoliniferous sands in FA3) and in sand/mud ratio with a predominance of sandy sediments on muds; besides, there is a broad predominance of sheet on channelled sandstones (3.1 in Fig. 8). Channels at FA3, however, are even more deeply

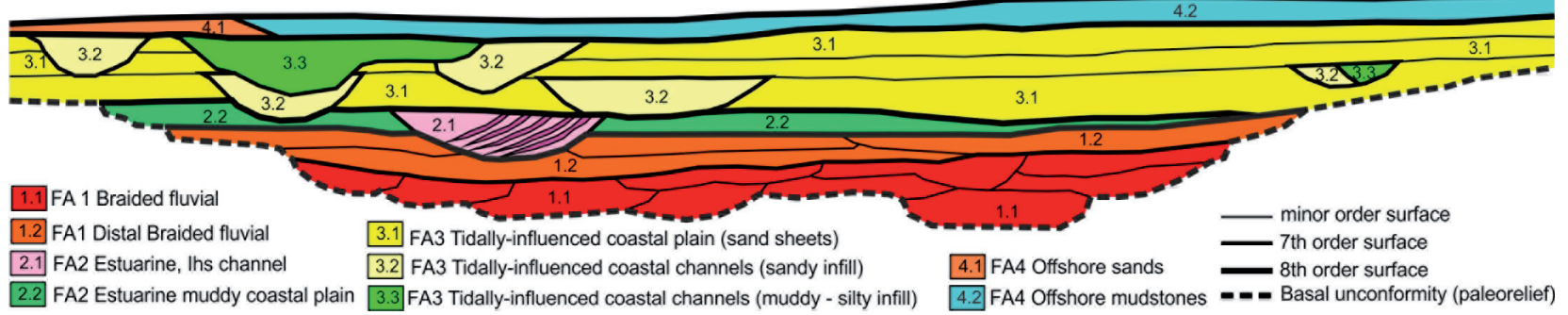

Fig. 8.- Depositional architecture with a stratigraphic cross section (not to scale) showing the main bounding surfaces interpreted from the different facies associations along the studied area, which is about $6 \mathrm{~km}$ long $(\mathrm{N}-\mathrm{S})$. 

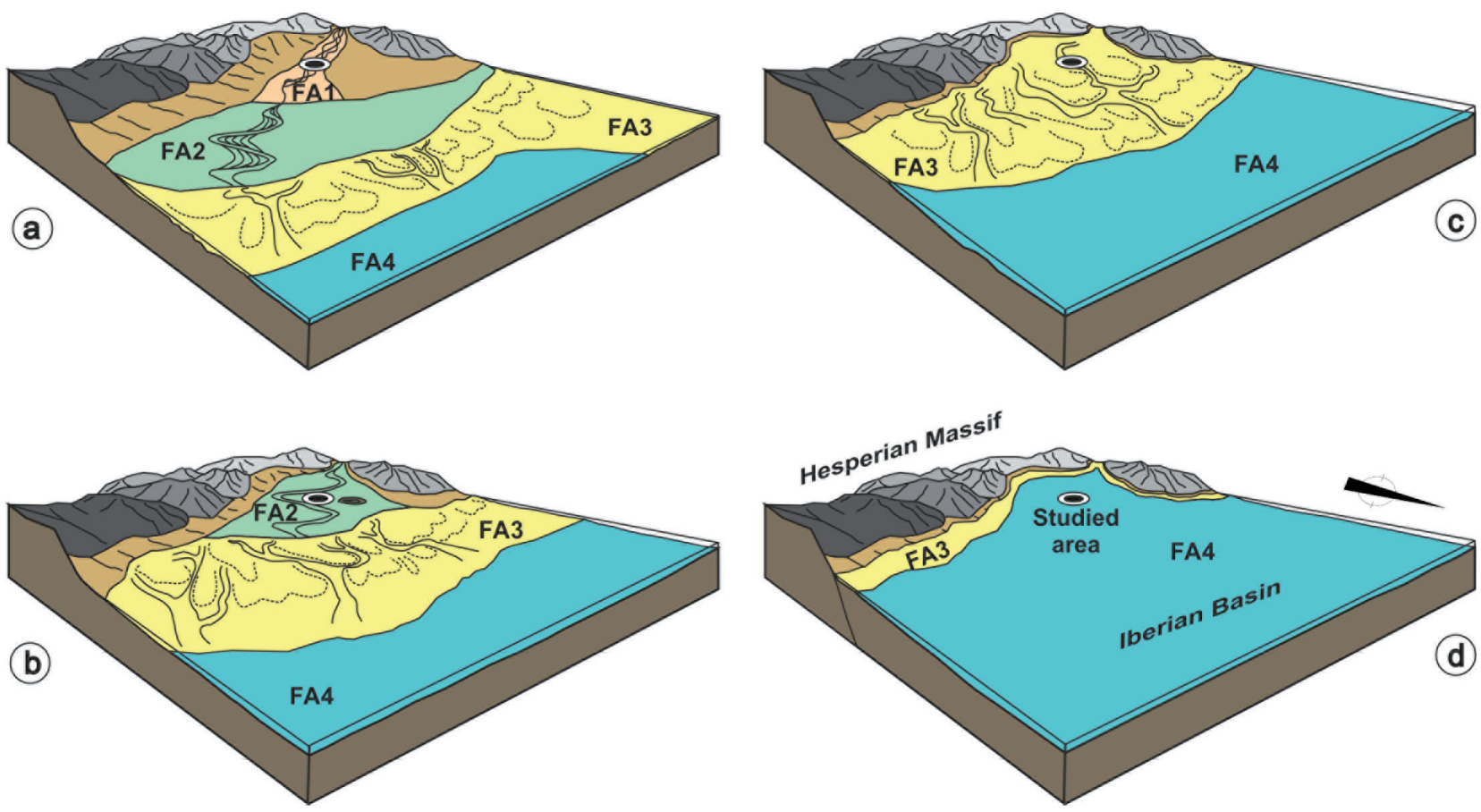

Fig. 9.- Palaeogeographic sketches of the different facies associations showing environmental interpretation for the different facies associations: a, FA1 interpreted as a fluvial braided environment; b, FA2 interpreted as a fluvial-estuarine environment with meandering channels (Ihs facies); c, FA3 interpreted as a tidal environment with channels (continuous line) and bars (dots); d) FA4 interpreted as an offshore environment.

incised (3.2 and 3.3 in Fig. 8), and cross-bedding showing important differences regarding the underlying FA1-FA2 (see section 5.3 below) (Fig. 5a and b). Together with all these architectural changes, the sandstones also show a coarsening trend in maximum clast size regarding the underlying FA2.

The abundance of quartz and quartzite, extrabasinal clasts indicates that the sedimentary environment was connected to an extrabasinal provenance and were not isolated tidal channels (Fig. 9c). Considering the vertical stacking pattern of the different facies associations, a reasonable interpretation is that sediment was supplied first by bedload-dominated, fluvial systems, similar to the underlying FA1, during flooding events, and then by tidal-fluvial estuarine systems as FA2 (Fig. 9a and b). Sediment was deposited as bars and reworked by tidal currents into a series of coalescing bars and channels.

Tidal and estuarine facies models are characterized by complex networks of tidal channels and bars (Fig. 9c). This originates a complex sedimentary architecture since the migration and stacking of small and large channels, and successive simple and compound bars produce the development of erosive bounding surfaces of several different orders (Fig. 8). In this case, the erosional combination of channels and sheet sediments also makes it difficult to recognize any larger-scale stratigraphic trends that might originally exist. It is worth noting that, the described environment differs from most tidal facies models by the lack of the low-energy, mud-flat deposits characteristic of these environments.

Finally, the disappearance of channelled deposits and the predominance of muddy facies at the top of the studied sec- tion involve another major change in depositional architecture (Fig. 8) with a transition to an offshore marine environment (Fig. 9d)

\subsection{Large-scale, very thick sets of planar (solitary) cross- beds in FA3}

The presence of fine to coarse-grained sandstones, and even conglomerates in large-scale and very thick sets of planar (solitary) cross-beds (Fig. 5a), are the most striking feature of FA3. These large-scale cross-beds are up to $4 \mathrm{~m}$ thick and may extend across several hundred meters long (up to 150 $\mathrm{m}$ wide), with a single individual set of uniform thickness apparently accreting laterally. Given the related environment (see above), they might resemble sand-waves, delta foresets or aeolian dunes.

Very thick beds composed of a large scale, single set of cross-bedded sands or sandstones and conglomerates are commonly described in ancient and modern environments. With the exception of deep sea environments, they have been described in tidal environments, where considering their sizes (length and height), the original bedforms have been termed sand-waves, giant dunes or very large tidal dunes (Ashley, 1990; Smith, 1992); with heights up to $40 \mathrm{~m}$ high (e.g., Arnaud, 2004; Martín et al., 2009).

Simple dunes can form in high-energy, deep water tidal environments (Olariu et al., 2012). In most estuarine and deltaic settings they commonly have a fining upward trend from bioturbated muddy sands to sandy ripples, and to stacked simple 
dunes (Olariu et al., 2012); their lower bounding surfaces are planar (at outcrop scale) and mainly horizontal or dipping at a low angles (Arnaud, 2004). In these environments they are not solitary, single sets of cross-beds; they, however, are usually part of composite, compound dunes with reverse crossbedding directions and abundant reactivation surfaces (Arnaud, 2004; Martín et al., 2009; Olariu et al., 2012).

The large-scale sets of cross-bedded conglomerates and sandstones also resemble the coarse-grained Gilbert-type deltas or tidal deltas (e.g. Limarino et al., 2002; Longhitano, 2008; Breda et al., 2009; Leren et al., 2010), although these show slightly thinner cross-bedded sets than tidal dunes, they are in the range of the beds described in this paper.

Finally, in aeolian dunes the large-scale cross-stratification mostly forms a single set and is laterally discontinuous. These sets of large and very large-scale tabular planar crossstratification usually reach up to $15 \mathrm{~m}$ high (e.g., Ahlbrandt and Fryberger, 1982; Limarino and Spalleti, 1986; GarcíaHidalgo et al., 2002).

In either case, however, the main difference with all these environments is that in this case these large-scale cross sets filled entirely up a single channel. Channel forms are commonly 1 to $5 \mathrm{~m}$ thick and 10 to $150 \mathrm{~m}$ wide (Fig. 8). Channels are predepositional sedimentary structures, initiated by localized linear erosion by a fluid flow with the aid of bed load. Once a channel is established, usually, a lateral component of erosion develops in a margin and a component of sedimentation also develops in the opposite margin. Many channels described in this paper are cut-and-fill structures, but they are small-scale channels; or channels with a later infill by sandy bedforms (Fig. 5a).

The large-scale cross sets are confined in U-shaped concave-up channel forms, which erosionally cut into adjacent strata (Fig. 5a). When the entire channel and bedform are observed the geometric disposition of cross beds are strictly parallel to the erosive margin of the channel. Then, the cross set seem to be developed from lateral accretion, but with a single prograding foreset. The entire channel was probable eroded also in a single event, because the opposite margin usually develops a thin bed with a ferruginous crust. The presence in the crusts of wrinkle structures and vertebrate track suggests that channels were open, but with water along enough time to allow these features to form (see section 5.4 for a further description and discussion). Final channel infill may correspond either to cross-bedded sands apparently with shorterscale beds and smaller dips or with siltstones and mudstones (mud plug, Fig. 4f).

The absence of bottomset and topset deposits suggests that these large-scale cross sets are not delta foresets; besides delta foresets are not channelized. Such large cross-sets are commonly found as sand waves in deep water, tidal environments or in aeolian environments, but they are not channelized either. They are consequently interpreted as distributary channels in intertidal-subtidal coastal environments (see section 4.3 for a further discussion).

\subsection{Implications of cross-bedding styles}

A further distinctive feature in FA3 is the overall aspect of the cross bedding (Fig. 10). Firstly, laminae in the cross-bedding are very thick, in the range of bedding. Laminae thickness of 20-60 $\mathrm{mm}$ and up to $80-100 \mathrm{~mm}$ are common (Fig. 10). Secondly, they are locally very large; although the norm is several $\mathrm{cm}$ to $\mathrm{dm}$ long, they can reach up to 3-4 $\mathrm{m}$ in length (Fig 5a). Moreover, there is a predominance of a rhythmic cross-bedding, which appears to be more "regular" with lateral, systematic variations in grain size and tends to be more planar-tabular that characterises the cross bedding in underlying deposits or other sediments (Fig. 10). In cross-stream view, the overall cross strata are planar or slightly concave (Fig. 10). The contact between the cross strata and the basal bedform surface is angular or slightly tangential.

Cross-bedding in FA3 apparently consists of couplets of related of coarser-grained and finer-grained laminae (Fig. 10a). These couplets seem to be two different modes of sorting along the cross beds, because the fine and coarse fractions are found at different laminae, with segregation of different grain sizes along the lee face. Mud drapes and conglomerate lags are also present along these cross-bedded deposits. The thicknesses of the coarse-grained cross strata ranged from 5 to $45 \mathrm{~mm}$; finer cross strata without visible internal structures ranged in thickness from 15 to $55 \mathrm{~mm}$. Considered as a single cross-bed lamina, both pair of laminae range from 20 to $100 \mathrm{~mm}$, which is very thick considered common cross bedding thickness, which averaged $30( \pm 10) \mathrm{mm}$ (Reesink and Bridge, 2009).

The basal, coarse-grained laminae of a couplet is erosionally-based, which enhance the striping pattern parallel to lee face (cross-stratification). The thickness of these cross laminae along the lee face is not constant and homogeneous (Fig. 10b). Some laminae thicken upwards along slip face and groups of thick laminae are followed by groups of thinner laminae (Fig. 10b). Several coarse-grained laminae may merge downward the lee face, forming a basal wedge of homogeneous coarse-grained sediments. There, cross bedding is not as clearly seen as in the middle or upper part of the bedform (Fig. 10b), due also to the absence of the finer-grained laminae in these wedges. Coarse-grained wedges rest sharply on the basal erosive surface; being, in this case, the basal surface more erosive than when no wedges are present. Coarsest grains accumulate at base of the cross-set forming a gravel lag (Fig. 10a). When no lags or wedges are present, coarsegrained laminae rest with a sharp, angular contact directly on the basal erosive surface (Fig. 10a). Within coarse-grained laminae the sediment is often sorted vertically. The coarsest grains usually are mainly deposited on the lower part of the lee slope, whereas the finer grains are predominantly deposited in the upper part (Fig. 10a). The result is that laminae becomes coarser grained down slope (fining upward sorting) and towards its inclined, basal surface (normally graded). Isolated, larger grains also rest on the inclined, basal surface 

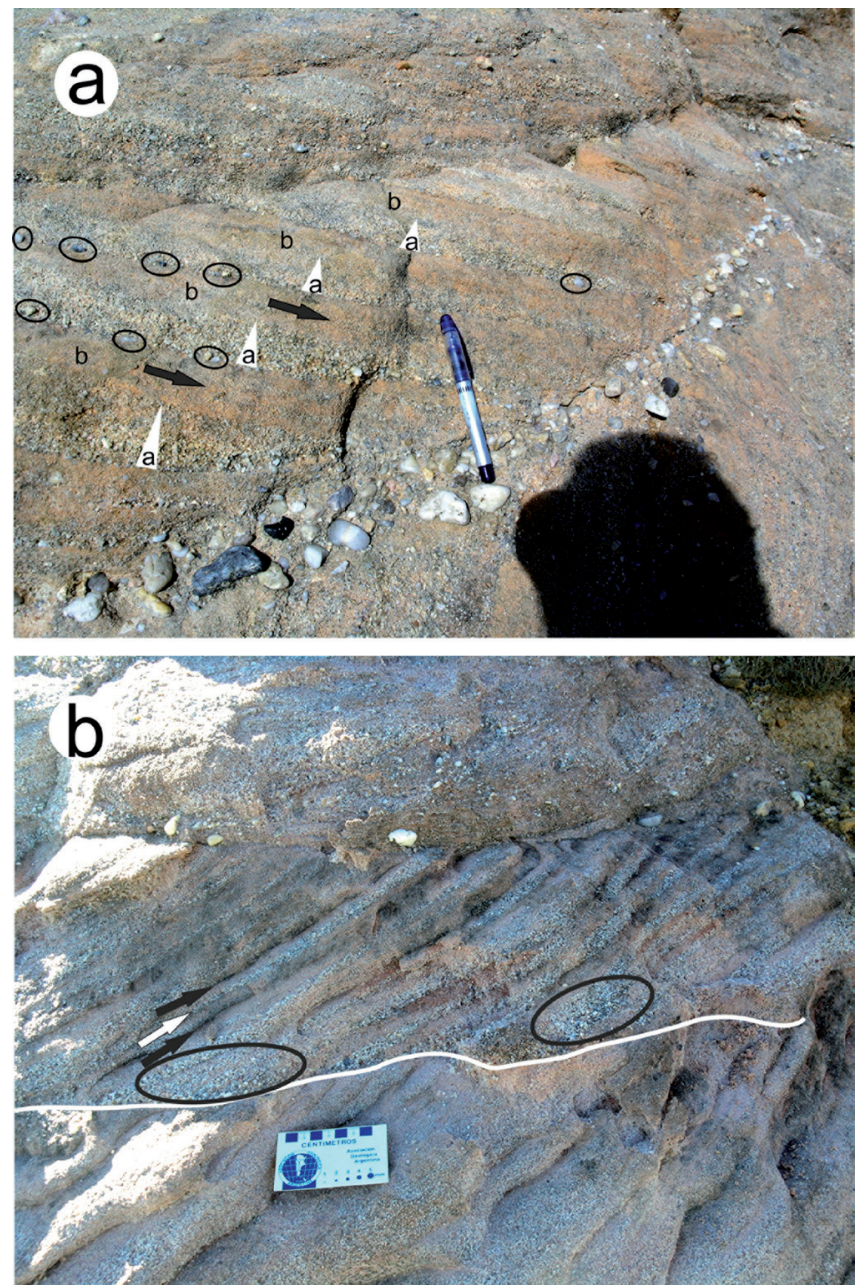

Fig. 10.- Main features of cross-bedding in FA3. a) Cross-bedding is mainly planar with very thick lamina alternation composed of coarser-grained (a) and finer-grained (b) laminae (pen for scale is $13.5 \mathrm{~cm}$ long); coarse-grained laminae are normally graded (white triangles) with granules (encircled) at the base with their longer axis paralleloriented to the base of the lamina; finer-grained lamina shows a smaller-scale lamination (black arrows). b) Ocasionally, coarser laminae show some thicker beds towards the upper part of the bedforms (white arrow); several laminae merge to granule wedge at the base (circles), where the basal erosive surface show a sligthly major incission. Minor silty drapes occur at the top of the finer-grained laminae (seen as thin, black stripes; black arrows).

of the cross laminae, with their longer axis aligned parallel to this inclined surface (Fig. 10a).

The upper, finer-grained laminae of a couplet apparently is internally massive as if the individual processes do not cause sufficient grain-size sorting to be identified as individual layers, but when laminae are thicker, they occasionally have subtle internal layering (Fig. 10a). The striping pattern of cross-bedding is not as clear in these laminae as in the coarser-grained ones.

Cross bedding is a common sedimentary structure in many depositional environments, being largely defined by internal grain size variations and sorting from fine sand to granules. Usual interpretation suggests the lower part of the couplet were probably deposited by grainflow (grain avalanche) along lee slopes, and the latter reflect subsequent deposition by grainfall (e.g., Passalia et al., 2016). Nevertheless, in sandy gravel sediments of subaqueous dunes, the cross-stratification mainly consists of grain flow deposits with little or no grain fall deposition on most of their lee faces (Kleinhans, 2004), suggesting that the sediment was delivered in pulses; rolling grain deposits for the coarsest sediments, however, are also common (Kleinhans, 2004). Kinetic sieving during grainflows (Makse et al., 1998; Dasgupta and Manna, 2011) causes the grainflow deposit to become coarser-grained down-slope and towards its outer edge (inversely-graded). When common and multiple grainflows are involved, however, the larger grains that are "pushed" upwards to the surface of the flow, have more occasions to reach the lower part of the lee face developing an overall net vertical fining upward trend. Thus, the largest grains end at the toe forming a wedge of coarser grains (Fig. 10b), grading upwards to relatively fine-grained sediments. In addition, the result is a normally graded lamina (Fig. 10a). Grains may also roll down individually and the largest grains may stay on the basal surface of the lee face (Fig. 10a).

Commonly, the cross strata formed in sandy gravel have an angular contact with the base (Fig. 10), which is usually attributed to the lack of significant deposition from suspension and the lack of reworking of the lee slope by turbulence (Reesink and Bridge, 2009). This feature also suggests that grain flow rather than grain fall dominates the deposition on the lee faces (Reesink and Bridge, 2007).

Nevertheless, grainflows did not commonly form cross strata with mixtures of different grain sizes, only grain-size segregation took place (Reesink and Bridge, 2007). In fact, with grain mixtures and coarser deposits the origin and development of the typical cross bedding is often related with grain-size sorting due to the presence either of superimposed bedforms or flow unsteadiness (Reesink and Bridge, 2007, 2009; Klienhans, 2004).

In the first case, the sediment within the overlying bedform is responsible for the formation of a relatively thick and coarse-grained cross stratum on the lee side of the host bedform (Reesink and Bridge, 2007, 2009). Deposition from suspension during the passage of the superimposed bedform troughs results in the formation of thin drapes of finer-grained sediments that define the coarse-grained body of the stratum. In the second case, the grain size of bedload is expected to decrease as flow stage decrease (Klienhans, 2001; Bridge, 2003; Klienhans, 2004); thus, relatively coarser sediments are deposited at high flow stage, and finer sediments at low flow one (Bridge, 2003; Klienhans, 2004). These changes in the grain size reflect then flow unsteadiness linked with cyclical variations in discharge, such as caused by tides.

The presence of subtle cross-bedding in the finer-grained part of the couplets seem to support this second case. Moreover, the presence of muddy drapes is generally thought to be formed by changes in the flow strength, with alternating tidal periods of flow and slack water (e.g. Darlymple, 1992; Olariu 
et al., 2012). These drapes are thin and scarce probably due to the relatively low suspended-sediment concentration.

The variations in current speed that take place in tidal environments may be expressed as regular variations in the grain size of adjacent laminae: medium to coarse sand in the laminae deposited by the stronger currents; finer sand in the laminae deposited by the slower currents. Such coarse-fine alternations can be considered as tidal, due to the presence of opposite paleocurrent pattern, tidal bundles and mud drapes in these facies. The presence of mud drapes represents an extreme case, with sedimentation from suspension during slack water periods. Finally, the largest grains that are in motion during the peak discharge will be deposited in the dune troughs during falling discharge, while the smaller grains remain in transport, resulting in the genesis of lag deposits, produced during a waning flow by peak flows (Klienhans, 2004). Some percolation of finer-grained sediments within the larger grains also occur while these grains are partially mobile or immobile during cross-bedding development.

\subsection{Ferruginous crusts (ironstones), wrinkle structures and vertebrate tracks}

The presence of ironstones, wrinkle structures and different kind of trace fossils (including vertebrate tracks) (Fig. 11), in the same beds, represents an uncommon and undescribed (up to date the authors do not know any paper describing it), combination of sedimentary structures whose mutual relationships help to understand different synsedimentary processes that occurred more or less at the same time, related to the development of these structures.

Ferruginous crusts described in this paper should be strictly considered ironstones, a term that can be used related to any iron-enriched sedimentary strata, irrespective of the mode of ferruginous enrichment (Tanner and Khalifa, 2010; for a discussion on terms such as ferricretes and laterites see also that paper). The lack of recognizable vertical pedogenic profiles suggests that these ironstones were not related to pedogenic process.

Some of the ironstones are clearly of secondary, diagenetic origin since they occur as thin ferruginious levels cutting across primary sedimentary structures, such as cross-bedding. In fact, there is abundant evidence of iron mobilization and recycling including extensive zones of bleaching and secondary ferrugenization within both basement and overlying sedimentary rocks in the region.

In other cases, however, they are related to thin sandstone beds composed of fine-grained, mainly quartzitic sandstones ( $>90 \%$ quartz grains). In this case, it is important to note that these ironstones are related to the presence of other sedimentary features, such as wrinkle structures (Fig. 11a, b), bioturbation (Fig. 11e), and vertebrate tracks (Fig. 11f) as discussed below.

"Wrinkle structures" (also named "wrinkle marks") are a group of sedimentary structures, characterized by the presence of more or less irregular, $\mathrm{mm}$ - to $\mathrm{cm}$-scale ridges and hollows that can occur on top of, or as casts at the sole of, beds (Hagadorn and Bottjer, 1999; Banerjee and Jeevankumar, 2005). They have been commonly described related to sandstones, both from marine and terrestrial settings (Noffke et al., 2002; Fedo and Cooper, 1990; Hagadorn and Bottjer, 1997; Pruss et al., 2004). Currently, in order to explain the formation of wrinkle structures, practically all authors suggest the presence of a cohesive microbial mat at the surface of the sediments (e.g., Hagadorn and Bottjer, 1997; Noffke et al., 2002), being commonly regarded as a "Microbially Induced Sedimentary Structure" (MISS, Noffke, 2009; see also this paper for a wide revision of this structure).

In the studied succession, wrinkle structures are related to thin bedded sandstones and comprise two main types. In the first type, the sandstone is covered by a thin muddy lamina (up to $1 \mathrm{~mm}$ thick), in which tiny clasts are only exceptionally visible (Fig. 11b). The surface can be either a slightly undulated, smooth surface with small, isolated millimetric knolls on bright red claystone, or a surface with rounded to subrounded bulges, commonly $0.5-2 \mathrm{~cm}$ in diameter, preserved as convex epirelief on the surface of the laminae, and depressions aligned in an irregular way (Fig. 11a, b). This kind of structures can be considered as "elephant skin" wrinkle structures (after Porada and Bouougri, 2007; Lan and Chen, 2013). The second type corresponds to small domal structures developed on sandstone bed tops, which are preserved as positive epirelief (Fig. 11c). The domes are mainly hemispherical, ranging from $0.8 \mathrm{~cm}$ to $2 \mathrm{~cm}$ in diameter and project up to $0.5-1 \mathrm{~cm}$ from bed surface. Distribution of the domes on the bed top is very irregular and some trace fossils (Planolites-type) are also present among and cross-cutting them. They have been termed "domal sand buildups" (Bottjer and Hagadorn, 2007) or gas domes (Lan and Chen, 2013); the first authors suggested that they originated as biofilm binding quartz sand grains in vertical direction (Bottjer and Hagadorn, 2007), meanwhile Lan and Chen (2013) suggested that they were originated by accumulation of gas, possibly $\mathrm{CO}_{2}$, $\mathrm{CH}_{4}$ and $\mathrm{H}_{2} \mathrm{~S}$ generated during organic decay, whose pressure to certain extent will eventually cause the upward movement of sand grains in the bed.

Wrinkle structures, similar to those presented here, have been widely described in siliciclastic peritidal environments. In these settings, cohesive microbial mats grow in the tidal zones, where energy is low; the most favourable conditions take place when sediment is not moved for some time, allowing initial settlement and establishment of microbial communities (Noffke, 2009). Thus, bedding planes are well preserved because, after deposition, MISS protected the bed surfaces against erosion (Noffke, 2009). Besides, sandy sediments have good capillarity capabilities providing mats with capillary water in short periods of subaerial exposure (Porada and Bouougri, 2007). Finally, the lack or reduced presence of predators (mainly gastropods) is also necessary, which commonly occur in hypersaline or tidal environments. 

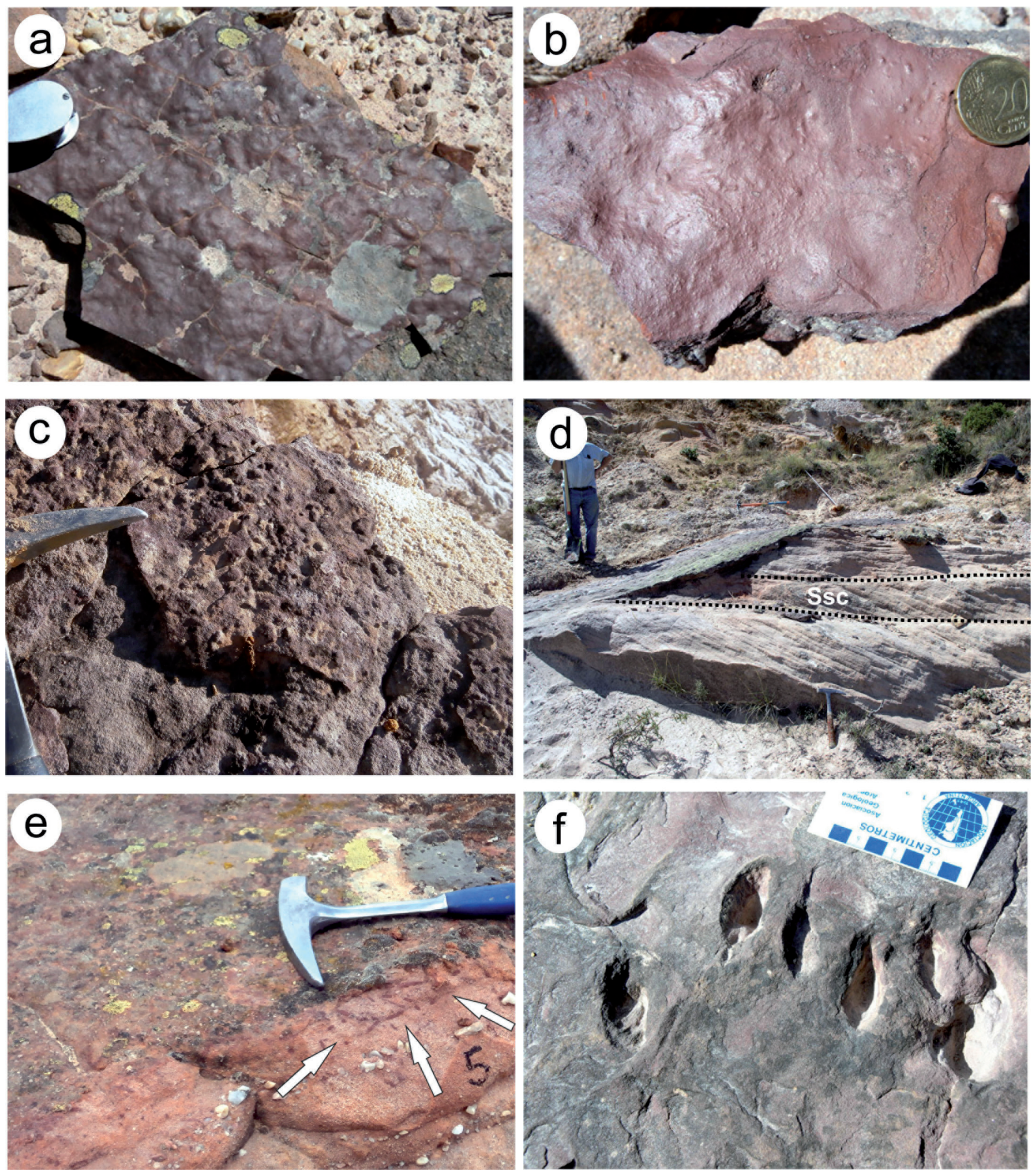

Fig. 11.- Ferruginous crusts, wrinkle marks and vertebrate traces. a) and b) two different kind of wrinkle marks, with small circular bulges (a) or with an undulated surface (b) on millimetre-thick red, ferruginous laminae; hand lens for scale in a) is $4 \mathrm{~cm}$ long, coin for scale in b). c) Domal structures in epirelief on a sandy ferruginous surface (hammer for scale). d) Base of a channel lined with a thin sandy ferruginous bed crowded with vertebrate traces (see f); the channel is eroded into sheet, cross-bedded sands (Ssc facies); the sandy bed was originally rippled and spilled out of the channel as shown by the change in dip towards the upper and right part of the picture (person and hammer for scale); the final infill of the channel is muddy at the feet of the person (Fig. 5e represents this channel infill). e) Planar ferruginous surface on sheet sandstones with burrows (white arrows) in the underlying sandstones filled with red sand of the crust. f) crocodile claws on the ferruginous bed surface; the trace show a deformed rim suggesting plastic behaviour of sand at the time of trace formation; the sand of the trace is dark red on the rim, ligther red immediately below and yellowish at the bottom of each claw suggesting that ferruginization was previous to the claw mark.

In one of the studied ironstones, ferruginous crusts and domal structures are also related to vertebrate tracks (Fig. 11f). The site is the lateral margin of a channel in FA3 (Segura et al., 2016). There, the lateral part of the channel is covered by a thin, up to $5 \mathrm{~cm}$-thick, fine-grained sand bed which also spilled out laterally from one of the banks of the channel (Fig. 11d). The local presence of a faintly lamination within this thin bed suggests that, in origin, this bed was rippled, although even when the sediment was still soft, the surface was smoothed and extensively covered with tracks and traces left 

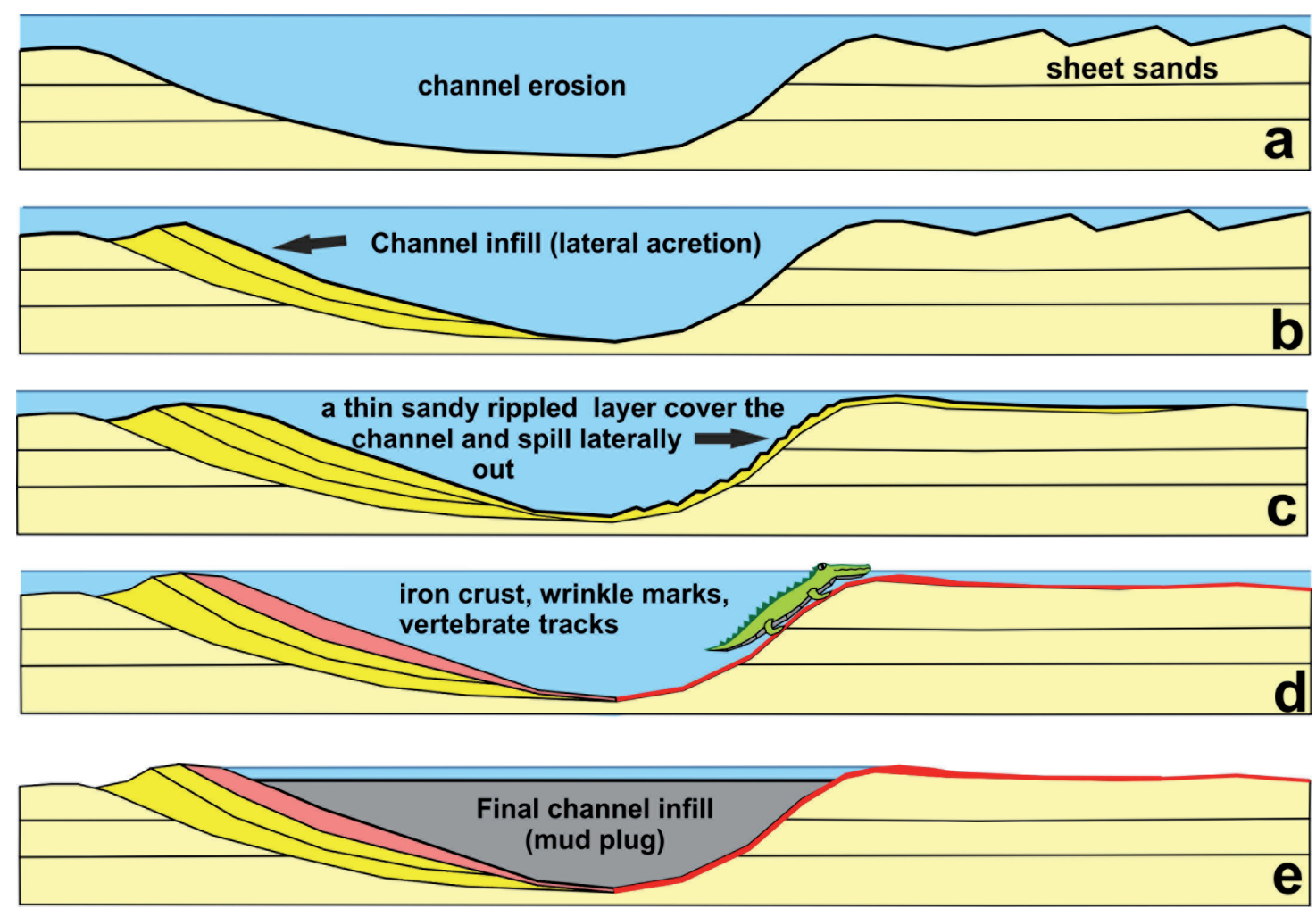

Fig. 12.- Interpretation, origin and development of channels with association of ferruginous crusts and vertebrate tracks in FA3. A tidal channel is eroded into sheet sands of FA3 (a). Start of channel infill by sands in lateral accretion cross beds (b). A thin, sandy rippled layer cover the channel and spill laterally out of the margins of the channel (c). Wrinkle marks, ferruginous crust development and vertebrate tracks formation, the channel remained open but was not an active site for sediment accumulation (d). Final muddy infill of the channel (mud plug, e).

by several vertebrate types, including fishes, crocodiles and a theropod (Segura et al., 2016). The domal structures are only located in the part of the bed located out, in the margin, of the channel. Nevertheless, although domal structures are only located at the margin of the channel, the overall impression is that the bed lining the channel was covered by a cohesive and sticky, soft lamina capable of plastic deformation, being locally corrugated and micro-folded, as commonly happen to wrinkle structures (Porada and Bouougri, 2007; Noffke, 2009).

This basal bed is extensively covered with tracks and traces as concave epirelief, sometimes with detailed morphology, bearing different orientations and morphologies, from entire manus and pes to only claws (Fig. 11f), suggesting that the channel was semi-permanently flooded at least, and that the time of track formation was long enough to cover the bed with many different traces and tracers.

Despite the low potential preservation of tracks in these tidal coastal systems, many different vertebrate tracks are found in this association. Preservation of vertebrate tracks in the stratigraphic record depends on taphonomic processes. Preservation is low if erosion is common or there are long periods of exposure and no-sedimentation; which is not the case, because tracks were preserved. On the other hand, preservation is high if the track were buried rapidly, lacking significant erosion on the substrate (Marty et al., 2009; Dai et al., 2015), which is neither the case because track density might also point out the existence of a prolonged period of time between the different events recorded in the bed (Segura et al., 2016). Several related processes might help then to traces preservation.

The sediment was water-saturated, since both desiccation cracks are completely absent, and well-defined displacement rims were formed, suggesting that the sediment still had a relatively high yield strength at the time of track formation. The 1-2 cm top part of the sandy bed is red, with a ferruginous crust, but the lower part is yellowish (Fig. 11f); which can be seen in some claw marks, in which the displacement rim is the darker red part of the bed, the sediment immediately below is dark red and the sediment at the bottom of the claw-mark is yellowish (Fig. 11f). These features indicate unambiguously that reddening and iron accumulation occurred soon after deposition of the host sediment and previous to the track formation, and that the iron was not a later diagenetic process. Or, conversely, all the sediment within the track would be reddish.

The preservation of these tracks is herein interpreted as related to two connected processes. Firstly, bed surface consolidation due the existence of algal biofilms (wrinkle structures), as previously described in similar cases by Avanzini (1998) and Carvalho et al. (2013) among others. Secondly, immediately after or at the same time, biostabilization of the sediments was followed by early or synsedimentary cementation (ironstone development), which prevented tracks from disintegration. 
The proposed succession of processes involved in the genesis of this association is then (Fig. 12): 1) channel erosion and start sandy channel infilling (Fig. 12a to b). 2) A sandy bed is formed along the channel and spread laterally out of the channel, probably related to higher tides (Fig. 12c); 3) Channel is abandoned as an active sedimentary channel, channel is permanently flooded, however; start MISS development and early ferruginous crust development (Fig. 12d). 3) Vertebrate tracks and other traces are produced (sediment is still soft) (Fig. 12d). 4) Channel is definitively abandoned, start gradual channel infilling by fine-grained facies ("mud plug") (Fig. 12e), tracks and traces preserved.

\section{Conclusions}

At the Tamajón section, the Utrillas Formation, shows a rapid up-section change at the onset of the Late Cretaceous transgression that flooded this part of the emerged Iberian Massif. Facies and architectural channel elements allow a clear distinction between the different facies associations (FA1 to FA4). FA1 is interpreted as a braided fluvial system by coarse grained facies, sedimentation of bedload bedforms and amalgamated channel systems. FA2 is interpreted as a distal fluvial-estuarine deposits because it is composed of large channel with inclined heterolithic stratification (Ihs) within overbank fine-grained sediments; Ihs is characteristic of meandering channels in these environments. FA3 is interpreted as tidal deposits based in the presence of paleocurrent pattern, herringbone cross stratification and mud drapes. The presence of channels, large-scale single set cross stratification, wrinkle structures and vertebrate tracks also support such interpretation. Finally, FA4 is interpreted as shallow offshore marine sediments because of the absence of channels and the common presence of burrowed fine-grained sandstones and mudstones.

The FA3 contains several peculiar sedimentary features. Firstly, the presence of large-scale cross sets infilling large erosive channels; these facies, if not considered the entire aspect of channels and related facies can be improperly interpreted as other, different facies (such as tidal deltas, sand waves or, even, aeolian deposits). Secondly, the presence of cross-bedding defined by couplets of different grain size are interpreted as originated by flow unsteadiness in relation to changing tides. The presence of mud drapes and gravel lags also suggests changes in flow strength. Finally, there is also an unusual association of ironstones, wrinkle structures and, burrows and vertebrate tracks. Some of the ironstones are of secondary, diagenetic origin. Nevertheless, thin ferruginous sandy beds and very thin, mm muddy ironstones are related to the presence of wrinkle structures and vertebrate tracks suggesting that iron encrusting was primary and synsedimentary. Wrinkle structures, are a kind of MISS, having been described in siliciclastic peritidal environments, where cohesive microbial mats may grow in favourable conditions. Despite the low potential preservation of tracks in these tidal coastal systems, vertebrate tracks are found in this facies. In this case, bearing in mind the local paleoenvironment, it is important to consider the different limiting factors on track preservation. Firstly, the consistency of the substrate at the time of track formation; the substrate was soft with an appropriate grain size. Secondly, after the track formation, tracks were not degraded, nor eroded or reworked during successive depositional events, even being found within a channel. Finally, the time between footprint formation and burial affects their preservation; but in this case it should be long enough to meet the features observed in the bed. Thus, the join presence of MISS structures (wrinkle marks) and early ferruginous stabilization of the sediment were probable the causes for track preservation.

\section{Acknowledgements}

This work was funded by Project PEII-2014-037-P of the Junta de Comunidades de Castilla-La Mancha. The authors would like to acknowledge Cesar Viseras and an anonymous reviewer for their valuable suggestions and comments to improve the manuscript.

\section{References}

Ahlbrandt, T.S., Fryberger, S.G. (1982): Introduction to eolian deposits. In: P.A. Scholle and D. Spearing (eds.), Sandstone Depositional Environments. American Association of Petroleum Geologists Memoir $31,11-47$.

Arnaud, E. (2004): Giant cross-beds in the Neoproterozoic Port Askaig Formation, Scotland: implications for snowball Earth. Sedimentary Geology 165, 155-174. doi:10.1016/j.sedgeo.2003.11.015.

Ashley, G.M. (1990): Classification of large-scale subaqueous bedforms: a new look at an old problem. Journal of Sedimentary Petrology 60, 160-172. doi: 10.1306/212F9138-2B24-11D7-8648000102C1865D.

Ashworth, P.J., Best, J.L., Jones, M.A. (2007): The relationship between channel avulsion, flow occupancy and aggradation in braided rivers: insights from an experimental model. Sedimentology 54, 497-513. doi: 10.1111/j.1365-3091.2006.00845.x.

Avanzini, M. (1998): Anatomy of a footprint: Bioturbation as a key to understanding dinosaur walk dynamics. Ichnos 6, 129-139. doi:10.1080/10420949809386444.

Banerjee S., Jeevankumar T.S. (2005): Microbially originated wrinkle structures on sandstone and their stratigraphic context: Palaeoproterozoic Koldaha Shale, central India. Sedimentary Geology 176, 211-224. doi:10.1016/j.sedgeo.2004.12.013.

Benvenuti, M., del Conte, S. (2013): Facies and sequence stratigraphic modeling of a Upper Pliocene-Lower Pleistocene fluvial succession (Valdelsa Basin, central Italy). Sedimentary Geology 294, 303-314. doi:10.1016/j.sedgeo.2013.06.006.

Bottjer, D., Hagadorn, J.W. (2007): Mat growth features. In: J. Schieber, P.K. Bose, P.G. Eriksson, S. Banerjee, S. Sarkar, W. Altermann, O. Catuneau, (eds.), Atlas of Microbial Mat Features Preserved Within the Siliciclastic Rock Record, Atlas in Geosciences. Elsevier, Amsterdam, pp. 53-71.

Breda, A., Mellere, D., Massari, F., Asioli, A. (2009): Vertically stacked Gilbert-type deltas of Ventimiglia (NW Italy): The Pliocene record of an overfilled Messinian incised valley. Sedimentary Geology 219, 58-76. doi:10.1016/j.sedgeo.2009.04.010.

Bridge, J.S. (2003): Rivers and Floodplains: Forms, Processes and Sed- 
imentary Record. Blackwell Publishing, Oxford, $504 \mathrm{p}$.

Bridge, J. (2006): Fluvial facies models: recent developments. In: H.W. Posamentier, R.G. Walker (eds.), Facies Models Revisited. SEPM, Special Publication 84, 85-117.

Cant, D.J., Walker, R.G. (1978): Fluvial processes and facies sequences in the sandy braided South Saskatchewan River, Canada. Sedimentology 25, 625-648. doi: 10.1111/j.1365-3091.1978.tb00323.x.

Carvalho, I.S., Borghi, L., Leonardi, G. (2013): Preservation of dinosaur tracks induced by microbial mats in the Sousa Basin (Lower Cretaceous), Brazil. Cretaceous Research 44, 112-121. doi:10.1016/j.cretres.2013.04.004.

Choi, K.S. (2010): Rhythmic climbing-ripple cross-lamination in inclined heterolithic stratification (IHS) of a macrotidal estuarine channel, Gosmo Bay, west coast of Korea. Journal of Sedimentary Research 80, 550-561. doi: 10.2110/jsr.2010.054.

Collinson, J.D., Thompson, D.B. (1982): Sedimentary Structures. London: George Allen \& Unwin, $194 \mathrm{p}$.

Dai, H., Xing, L., Marty, D., Zhang, J., Scott Persons IV, W., Hu, H., Wang, F. (2015): Microbially-induced sedimentary wrinkle structures and possible impact of microbial mats for the enhanced preservation of dinosaur tracks from the Lower Cretaceous Jiaguan Formation near Qijiang (Chongqing, China). Cretaceous Research 53, 98-109. doi:10.1016/j.cretres.2014.10.012.

Dalrymple, R.W. (1992): Tidal depositional systems. In: R.G. Walker, N.P. James (eds.), Facies Models, Response to Sea-level Changes. Geological Association of Canada, St John's, Newfoundland, pp. 195-218.

Dalrymple, R.W., Knight, R.J., Zaitlin, B.A., Middelton, G.V. (1990): Dynamics and facies model of a macrotidal sand-bar complex, Cobequid Bay-Salmon River Estuary (Bay of Fundy). Sedimentology 37, 577-612. doi: 10.1111/j.1365-3091.1990.tb00624.x.

Dalrymple, R.W., Baker, E.K., Harris, P.T., Hughes, M. (2003): Sedimentology and stratigraphy of a tide-dominated, foreland-basin delta (Fly River, Papua New Guinea). In: F.H. Sidi, D. Nummedal, P. Imbert, H. Darman, H.W. Posamentier (eds.), Tropical Deltas of Southeast Asia - Sedimentology, Stratigraphy, and Petroleum Geology. SEPM Special Publication 76, 147-173.

Dalrymple, R.W., Choi, K.S. (2007): Morphologic and facies trends through the fluvial marine transition in tide-dominated depositional systems: a schematic framework for environmental and sequencestratigraphic interpretation. Earth-Science Reviews 81, 135-174. doi:10.1016/j.earscirev.2006.10.002.

Dasgupta, P., Manna, P. (2011): Geometrical mechanism of inverse grading in grain-flow deposits: An experimental revelation. EarthScience Reviews 104, 186-198. doi:10.1016/j.earscirev.2010.10.002.

Dieguez, C., Peyrot, D., Barrón, E. (2010): Floristic and vegetational changes in the Iberian Peninsula during Jurassic and Cretaceous. Review of palaeobotany and Palynology 162, 325-340. doi:10.1016/j. revpalbo.2010.06.004.

Fedo, C.M., Cooper, J.D. (1990): Braided fluvial to marine transition: the basal Lower Cambrian Wood Canyon Formation, southern Marble Mountains, Mojave Desert, California. Journal of Sedimentary Petrology 60, 220-234.

Fenies, H., Tastet, J. (1998): Facies and architecture of an estuarine tidal bar (the Trompeloup bar, Gironde Estuary, SW France). Marine Geology 150, 149-169. doi:10.1016/S0025-3227(98)00059-0.

Fluteau, F., Ramstein, G., Besse, J., Guiraud, R., Masse, J.P. (2007): Impacts of palaeogeography and sea level changes on Mid-Cretaceous climate. Palaeogeography Palaeoclimatology Palaeoecology 247, 357-381. doi:10.1016/j.palaeo.2006.11.016.

García-Hidalgo, J.F., Temiño, J., Segura, M. (2002): Holocene eolian sediments on the southern border of the Duero basin (Spain): origin and development of an eolian system in a temperate zone. Journal of Sedimentary Research 72, 30-39.
García-Hidalgo, J.F., Gil, J., Segura, M., Domínguez, C. (2007): Internal anatomy of a mixed siliciclastic-carbonate platform: The Late Cenomanian-Mid Turonian at the southern margin of the Spanish Central System. Sedimentology 54, 1245-1271. doi: 10.1111/j.13653091.2007.00880.x

Gil, J., Carenas, B., Segura, M., García-Hidalgo, J.F., García, A., (2004): Revisión y correlación de las unidades litoestratigráficas del Cretácico Superior en la región central y oriental de España. Revista de la Sociedad Geológica de España 17, 249-266.

Gil-Gil, J., Fernández-Marrón, M.T., García-Hidalgo, J.F., Segura, M., Fonollá-Ocete, J.F. (2013): Palinología del Turoniense en el sinclinorio de Campisábalos: aportaciones al análisis estratigráfico secuencial (Sistema Central-Cordillera Ibérica; Guadalajara-Segovia, España). Revista de la Sociedad Geológica de España 26, 23-36.

González-Casado, J.M., Caballero, J.M., Casquet, C., Galindo, C., Tornos, F. (1996): Paleostress and geotectonic interpretation of the Alpine Cycle onset in the Sierra del Guadarrama (eastern Iberian Central System), based on evidence from episyenites. Tectonophysics 262, 213-229. doi:10.1016/0040-1951(96)00004-2.

Hagadorn, J.W., Bottjer, D.J. (1997): Wrinkle structures: microbially mediated sedimentary structures in siliciclastic settings at the Proterozoic-Phanerozoic transition. Geology 25, 1047-1050. doi: 10.1130/0091-7613(1997)025<1047:WSMMSS>2.3.CO;2.

Hagadorn J.W., Bottjer, D.J. (1999): Restriction of a Late Neoproterozoic biotope: suspect-microbial structures and trace fossils at the Vendian-Cambrian transition. Palaios 14, 73-85. doi: 10.2307/3515362.

Harris, P.T. (1988): Large scale bedforms as indicators of mutually evasive sand transport and the sequential infilling of wide-mouthed estuaries. Sedimentary Geology 57, 273-298. doi:10.1016/00370738(88)90034-6.

Heinberg, C., Birkelund, T. (1984): Trace-fossil assemblages and basin evolution of the Vardekløft Formation (Middle Jurassic, Central East Greenland). Journal of Paleontology 58, 362-397.

Hernáiz, P.P., López Olmedo, F., Cabra, P., Solé, J., Escuder, J., Valverde, P., Dunning, G., Bea, F., Gálvez García, C. (2005): Hoja geológica num. 459 (Tamajón). Mapa Geológico de España E. 1:50.000. Segunda serie, I.G.M.E., Madrid.

Hori, K., Saito, Y., Zhang, Q., Wang, P. (2002): Architecture and evolution of the tide-dominated Changjiang (Yangtze) River delta, China. Sedimentary Geology 146, 249-264. doi:10.1016/S00370738(01)00122-1.

Johnson, S.M., Dashtgard, S.E. (2014): Inclined heterolithic stratification in a mixed tidal-fluvial channel: Differentiating tidal versus fluvial controls on sedimentation. Sedimentary Geology 301, 41-53. doi:10.1016/j.sedgeo.2013.12.004.

Kleinhans, M.G. (2001): The key role of fluvial dunes in transport and deposition of sand-gravel mixtures, a preliminary note. Sedimentary Geology 143, 7-13. doi:10.1016/S0037-0738(01)00109-9.

Kleinhans M.G. (2004): Sorting in grain flows at the lee side of dunes. Earth-Science Reviews 65, 75-102. doi:10.1016/S00128252(03)00081-3.

Lan, Z.W., Chen, Z.Q. (2013): Proliferation of MISS-forming microbial mats after the late Neoproterozoic glaciations: Evidence from the Kimberley region, NW Australia. Precambrian Research 224, 529 550. doi:10.1016/j.precamres.2012.11.008.

Leren, B.L.S., Howell, J., Enge, H., Martinius, A.W. (2010): Controls on stratigraphic architecture in contemporaneous delta systems from the Eocene Roda Sandstone, Tremp-Graus Basin, northern Spain. Sedimentary Geology 229, 9-40. doi:10.1016/j.sedgeo.2010.03.013.

Limarino, C.O., Spalletti, L.A. (1986): Eolian permian deposits in west and northwest Argentina Sedimentary Geology 49, 109-127. doi:10.1016/0037-0738(86)90017-5.

Limarino, C.O., Césaria, S.N., Net, L.I., Marenssi, S.A., Gutierrez, R.P., Tripaldi, A. (2002): The Upper Carboniferous postglacial transgres- 
sion in the Paganzo and Río Blanco basins (northwestern Argentina): facies and stratigraphic significance. Journal of South American Earth Sciences 15, 445-460. doi:10.1016/S0895-9811(02)00048-2.

Longhitano, S. (2008): Sedimentary facies and sequence stratigraphy of coarse-grained Gilbert-type deltas within the Pliocene thrust-top Potenza Basin (Southern Apennines, Italy). Sedimentary Geology 210, 87-110. doi:10.1016/j.sedgeo.2008.07.004.

Makse, H.A., Ball, R.C., Stanley, H.E., Warr, S. (1998): Dynamics of granular stratification. Physical Review E 58, 3357-3367. doi: 10.1103/PhysRevE.58.3357.

Martín, J.M., Braga, J.C., Aguirre, J., Puga-Bernabéu, Á. (2009): History and evolution of the North-Betic Strait (Prebetic Zone, Betic Cordillera): A narrow, early Tortonian, tidal-dominated, AtlanticMediterranean marine passage. Sedimentary Geology 216, 80-90. doi:10.1016/j.sedgeo.2009.01.005.

Marty, D., Strasser, A., Meyer, C.A. (2009): Formation and taphonomy of human footprints in microbial mats of present-day tidal-flat environments: Implication for the study of fossil footprints. Ichnos 16, 127-142. doi:10.1080/10420940802471027

Mellere, D. (1994): Sequential development of an estuarine valley fill: the Twowells Tongue of the Dakota Sandstone, Acoma Basin, New Mexico. Journal of Sedimentary Research 64, 500-515.

Miall, A.D. (1985): Architecture-element analysis: a new method of facies analysis applied to fluvial deposits. Earth-Science Reviews 22, 261-308.

Miall, A.D. (1996): The Geology of Fluvial Deposits: Sedimentary Facies, Basin Analysis and Petroleum Geology. Springer-Verlag Inc., Heidelberg, $582 \mathrm{p}$.

Mojica, J., Wiedmann, J. (1977): Kreide-Entwicklung und Cénomanien/ Turonien-Grenze der mittleren Keltiberischen Ketten bei Nuévalos (prov. Zaragoza-Spanien): Eclogae Geologicae Helvetiae 70, 739759. http://dx.doi.org/10.5169/seals-164639.

Noffke, N. (2009): The criteria for the biogeneicity of microbially induced sedimentary structures (MISS) in Archean and younger, sandy deposits. Earth-Science Reviews 96, 173-180. doi:10.1016/j.earscirev.2008.08.002.

Noffke, N., Knoll, A.H., Grotzinger, J. (2002): Sedimentary controls on the formation and preservation of microbial mats in siliciclastic deposits: a case study from the upper Neoproterozoic Nama Group, Namibia. Palaios 17, 1-14. doi: 10.1669/0883-1351.

Olariu, C., Steel, R.J., Dalrymple, R.W., Gingras, M.K. (2012): Tidal dunes versus tidal bars: The sedimentological and architectural characteristics of compound dunes in a tidal seaway, the lower Baronia Sandstone (Lower Eocene), Ager Basin, Spain. Sedimentary Geology 279, 134-155. doi:10.1016/j.sedgeo.2012.07.018.

Passalia, M.G., Llorens, M., Césari, S.N., Limarino, C.O., Perez Loinaze, V.S., Vera, E.I. (2016): Revised stratigraphic framework of the Cretaceous in the Bajo Grande area (Argentinean Patagonia) inferred from new U-Pb ages and palynology. Cretaceous Research 60, 152 166. doi:10.1016/j.cretres.2015.11.004.

Peyrot, D., Barrón, E., Comas-Rengifo, M.J., Barroso-Barcenilla, F., Feist-Burkhardt, S. (2008): Palinología del tránsito Cenomaniense/ Turoniense en la sección de Puentedey (Burgos, España). Coloquios de Paleontología 58, 101-161.

Porada, H., Bouougri E.H. (2007): Wrinkle structures - a critical review. Earth-Science Reviews 81, 199-215. doi:10.1016/j.earscirev.2006.12.001.

Portero García, J.M., Díaz Molina, M., González Lodeiro, F., Pérez González, A., Gallardo, J., Aguilar, M. J., Leal, M.C. (1990): Hoja geológica num. 485 (Valdepeñas de la Sierra). Mapa Geológico de España E. 1:50.000. Segunda serie, I.G.M.E., Madrid.

Pruss, S., Frasier, M., Bottjer, D.J. (2004): Proliferation of Early Triassic wrinkle structures: implications for environmental stress following the end-Permian extinction. Geology 32, 461-464. doi: 10.1130/
G20354.1

Reesink, A.J.H., Bridge, J.S. (2007): Influence of superimposed bedforms and flow unsteadiness on formation of cross strata in dunes and unit bars. Sedimentary Geology 202, 281-296. doi:10.1016/j.sedgeo.2007.02.005.

Reesink, A.J.H., Bridge J.S. (2009): Influence of bedform superimposition and flow unsteadiness on the formation of cross strata in dunes and unit bars - Part 2, further experiments. Sedimentary Geology 222, 274-300. doi:10.1016/j.sedgeo.2009.09.014.

Salas, R., Casas, A. (1993): Mesozoic extensional tectonics, stratigraphy and crustal evolution during the Alpine cycle of the eastern Iberian basin, Tectonophysics 228, 33-55. doi:10.1016/0040-1951(93)90213-4.

Schwartz, T.M., Graham, S.A. (2015): Stratigraphic architecture of a tide-influenced shelf-edge delta, Upper Cretaceous Dorotea Formation, Magallanes-Austral Basin, Patagonia. Sedimentology 62, 10391077. doi: $10.1111 /$ sed.12176.

Segura, M., Wiedmann, J. (1982): La transgresión del Cretácico Superior en el sector de Atienza Sigüenza (Guadalajara, Cordillera Ibérica) y el significado de la fauna Ammonitífera. Cuadernos de Geología Ibérica 8, 293-307.

Segura, M., García-Hidalgo, J.F., Carenas, B., Gil, J., García, A. (2004): Evolución paleogeográfica de la Cuenca Ibérica en el Cretácico Superior. Geogaceta 36,103-106.

Segura, M., Barroso-Barcenilla, F., Berrocal-Casero, M., Castanera, D., García-Hidalgo, J.F., Santos, V.F. (2016): A new Cenomanian vertebrate tracksite at Tamajón (Guadalajara, Spain): Palaeoichnology and palaeoenvironmental implications. Cretaceous Research 57, 508-518. doi:10.1016/j.cretres.2015.04.011.

Segura, M., Elorza, J. (2013): Presencia de ventifactos en las facies Utrillas (Tamajón-Sacedoncillo, borde Suroriental del Sistema Central, Guadalajara): aspectos morfológicos y procedencia. Revista de la Sociedad Geológica de España 26, 47-63.

Shiers, M.N., Mountney, N.P., Hodgson, D.M., Cobain, S.L. (2014): Depositional controls on tidally influenced fluvial successions, Neslen Formation, Utah, USA. Sedimentary Geology 311, 1-16. doi:10.1016/j.sedgeo.2014.06.005.

Sisulak, C.F., Dashtgard, S.E. (2012): Seasonal controls on the development and character of inclined heterolithic stratification in a tide-influenced, fluvially dominated channel: Fraser River, Canada. Journal of Sedimentary Research 82, 244-257. doi: 10.2110/jsr.2012.21.

Smith, A.M. (1992): Subaqueous giant (15 m) and supergiant (40 m) dunes from the Lower Permian Vryheid Formation of the Karoo Supergroup, northern Natal, South Africa. Sedimentary Geology 77, 215-224. doi:10.1016/0037-0738(92)90127-D.

Smith, D.G., Hubbard, S.M., Leckie, D.A., Fustic, M. (2009): Counter point bar deposits: lithofacies and reservoir significance in the meandering modern Peace River and ancient McMurray Formation, Alberta, Canada. Sedimentology 56, 1655-1669. doi: 10.1111/j.13653091.2009.01050.x.

Tanner, L.H., Khalifa, M.A. (2010): Origin of ferricretes in fluvial-marine deposits of the Lower Cenomanian Bahariya Formation, Bahariya Oasis, Western Desert, Egypt. Journal of African Earth Sciences 56, 179-189. doi:10.1016/j.jafrearsci.2009.07.004.

Thomas, R.G., Smith, D.G., Wood, J.M., Visser, J., Calverley-Range, E.A., Koster, E.H. (1987): Inclined heterolithic stratification-terminology, description, interpretation and significance. Sedimentary Geology 53, 123-179. doi:10.1016/S0037-0738(87)80006-4.

Wiedmann, J. (1975): Subdivisiones y precisiones bioestratigráficas en el Cretácico superior de las Cadenas Celtibéricas. Actas $1^{\circ}$ Simposium Cretácico Cordillera Ibérica, 135-154.

Willis, B.J. (2005): Deposits of tide-influenced river deltas. In: L. Giosian, J.P. Bhattacharya (eds.), River deltas: Concepts, Models and Examples. SEPM, Special Publication 83, Tulsa, pp. 87-129. 